\title{
Decay of a long-term monitored glacier: Careser Glacier (Ortles-Cevedale, European Alps)
}

\author{
L. Carturan ${ }^{1}$, C. Baroni ${ }^{2}$, M. Becker ${ }^{3}$, A. Bellin ${ }^{4}$, O. Cainelli ${ }^{4}$, A. Carton $^{5}$, C. Casarotto $^{6}$, G. Dalla Fontana ${ }^{1}$, \\ A. Godio ${ }^{7}$, T. Martinelli ${ }^{4}$, M. C. Salvatore ${ }^{2}$, and R. Seppi ${ }^{8}$ \\ ${ }^{1}$ Department of Land, Environment, Agriculture and Forestry, University of Padova, Agripolis, Viale dell'Università 16, \\ 35020 Legnaro, Padua, Italy \\ ${ }^{2}$ Department of Earth Sciences, University of Pisa, Via S. Maria 53, 56126 Pisa, Italy \\ ${ }^{3}$ Department of Geological Sciences, California State University, 1250 Bellflower Boulevard, Long Beach, CA 90840, USA \\ ${ }^{4}$ Department of Civil, Environmental and Mechanical Engineering (DICAM), University of Trento, Via Mesiano 77, 38123 \\ Trento, Italy \\ ${ }^{5}$ Department of Geosciences, University of Padova, Via G. Gradenigo 6, 35131 Padua, Italy \\ ${ }^{6}$ Museo delle Scienze, Via Calepina 14, 38122 Trento, Italy \\ ${ }^{7}$ Department of Environment, Land and Infrastructure Engineering, Politecnico di Torino, Corso Duca degli Abruzzi 24, \\ 10129 Turin, Italy \\ ${ }^{8}$ Department of Earth and Environmental Sciences, University of Pavia, Via Ferrata 1, 27100 Pavia, Italy
}

Correspondence to: L. Carturan (luca.carturan@unipd.it)

Received: 1 June 2013 - Published in The Cryosphere Discuss.: 3 July 2013

Revised: 30 October 2013 - Accepted: 3 November 2013 - Published: 3 December 2013

\begin{abstract}
The continuation of valuable, long-term glacier observation series is threatened by the accelerated mass loss which currently affects a large portion of so-called "benchmark" glaciers. In this work we present the evolution of the Careser Glacier, from the beginning of systematic observation at the end of the 19th century to its current condition in 2012. In addition to having one of the longest and richest observation records among the Italian glaciers, Careser is unique in the Italian Alps for its $46 \mathrm{yr}$ mass balance series that started in 1967. In the present study, variations in the length, area and volume of the glacier since 1897 are examined, updating and validating the series of direct mass balance observations and adding to the mass balance record into the past using the geodetic method. The glacier is currently strongly out of balance and in rapid decay; its average mass loss rate over the last 3 decades was $1.5 \mathrm{~m}$ water equivalent per year, increasing to $2.0 \mathrm{~m}$ water equivalent per year in the last decade. Although these rates are not representative at a regional scale, year-to-year variations in mass balance show an unexpected increase in correlation with other glaciers in the Alps, during the last 3 decades. If mass loss continues
\end{abstract}

at this pace, the glacier will disappear within a few decades, putting an end to this unique observation series.

\section{Introduction}

Long-term glacier observation series form the basis for the detection of secular trends and for the understanding of physical processes regulating the response of glaciers to climatic changes. Given their importance as key indicators of global climate change (Houghton et al., 2001; Solomon et al., 2007), glaciers are included in the terrestrial section of the Global Climate Observing System (GCOS/GTOS; GCOS, 2004). The Global Terrestrial Network for Glaciers (GTN-G), run by the World Glacier Monitoring Service (WGMS), follows a system of tiers that include the following: (1) intensive and integrated experimental sites aimed at increasing process understanding across environmental gradients, (2) processoriented mass balance studies within major climatic zones (about 10 glaciers worldwide), (3) glacier mass changes within major mountain systems (about 50 glaciers worldwide), (4) long-term measurements of length change at about 
10 sites within each mountain range (about 800 glaciers worldwide), and (5) repeated glacier inventories from satellite data (Haeberli, 2004; Haeberli et al., 2000, 2002).

Whereas glacier mass balance represents a direct and undelayed signal of climatic change, changes in glacier length primarily constitute an indirect, delayed and filtered, but also enhanced in terms of geometric adjustments, signal (Haeberli, 1995). Long time series of direct mass balance observations (cf. Østrem and Brugman, 1991), based on highdensity networks of stakes and firn pits, are especially valuable for analysing processes of mass and energy exchange at glacier-atmosphere interfaces and, hence, for interpreting climate-glacier relationships (WGMS, 2011). However, long and continuous series of annual/seasonal glacier-wide mass balance measurements represent only a small subset of total mass balance investigations. Among the $\sim 300$ glaciers where such measurements have been carried out, just 31 have been subject to continuous measurement programmes dating back to 1970 , and only 12 back to 1960 (WGMS, 2011; Zemp et al., 2009).

The continuation of these rare observation series, and their significance, is challenged by the rapid environmental changes which have lead to widespread reduction of glaciers worldwide; in many cases the last 2 decades have been characterised by a significant acceleration in glacier shrinkage compared to secular rates of glacier recession (Haeberli et al., 1999; Zemp et al., 2005; WGMS, 2011, 2012). Reinforcing mechanisms (e.g. lowered albedo, thermal emission from growing rock outcrops, lowered elevation, collapse structures) act as positive feedbacks once deglaciation has started, contributing to the observed acceleration of mass loss rates. Downwasting (i.e. stationary thinning) and rapid fragmentation are commonly recorded during this final stage of deglaciation in glaciers undergoing extinction under current climatic conditions. As a result, important consequences and new challenges are emerging for future glacier monitoring strategies, the most important of which is probably the complete loss of glaciers with long-term mass balance series (Paul et al., 2007).

The present work reports on the evolution of the Careser Glacier in the eastern Italian Alps since measurements began at the end of the 19th century. The dynamics of this glacier have been well documented during the last 115 years, thanks to the monitoring activities of the Comitato Glaciologico Italiano (CGI) and of the company exploiting its meltwater for hydropower generation (CGI, 1914-1977 and 1978-2012). As one of the few Tier 3 monitoring sites in the world with a $46 \mathrm{yr}$ continuous time series of mass balance measurements (only 22 glaciers worldwide have longer series; Zemp et al., 2009), the Careser Glacier is frequently referred to as an emblematic example of accelerated deglaciation and of vanishing glaciers with long-term mass balance observation series (e.g. Paul et al., 2007; Pecci et al., 2008; Paul, 2010; Gabrielli et al., 2010; Haeberli, 2011). The aims of this work are as follows: (i) to document the variations in length, area and vol- ume of the glacier since 1897; (ii) to update and validate the series of direct mass balance measurements; (iii) to compare the current mass loss rates with secular trends; and (iv) to outline the possible future evolution of the glacier.

\section{Geographic and climatic setting of the Careser Glacier}

The Careser Glacier (World Glacier Inventory code I4L00102519; WGMS, 1989) is a mountain glacier located in the south-eastern part of the Ortles-Cevedale massif (eastern Italian Alps), the largest glacierised mountain group of the Italian Alps (Carturan et al., 2013). The glacier occupies a wide, south-facing cirque surrounded by peaks ranging from $3162 \mathrm{~m}$ a.s.l. (Cima Lago Lungo) to $3386 \mathrm{~m}$ a.s.l. (Cima Venezia, Fig. 1), with bedrock composed of metamorphic rocks (mica schists and phyllites). Rather flat (average slope $=9^{\circ}$ ), the glacier currently (year 2012) extends from a minimum elevation of $2865 \mathrm{~m}$ a.s.l. to a maximum of $3280 \mathrm{~m}$ a.s.l., occupying a total area of $1.63 \mathrm{~km}^{2}$, which is subdivided into three main ice bodies and three smaller patches. The glacier is fed mainly during winter by direct precipitation and wind-drifted snow; avalanche contribution and topographic shading are of minor importance, given the small height difference between the glacier surface and the surrounding summits. For the same reason, debris cover is nearly absent. Meltwater feeds the Rio Careser, which drains into the river Noce, one of the tributaries of the river Adige. In the 1920s the Rio Careser was dammed at $2600 \mathrm{~m}$ a.s.l. for hydropower generation.

Climatically, the Ortles-Cevedale massif is near the main so-called "inner dry Alpine zone" (Schwarb, 2000), being characterised by the lowest precipitation in the entire European Alps $\left(500 \mathrm{~mm} \mathrm{yr}^{-1}\right.$ at the floor of the Venosta Valley). Precipitation does increase southward however, reaching $900 \mathrm{~mm} \mathrm{yr}^{-1}$ in the valleys at the southern edge of Ortles-Cevedale, while total annual precipitation of 1300$1500 \mathrm{~mm} \mathrm{yr}^{-1}$ has been estimated at $3000-3200 \mathrm{~m}$ a.s.l. in the area of the Careser Glacier itself (Carturan, 2010; Carturan et al., 2012). The mean annual $0{ }^{\circ} \mathrm{C}$ isotherm is located at around $2500 \mathrm{~m}$ a.s.l.

\section{Data sets and methods}

\subsection{Length changes}

The first investigations into the Careser Glacier were carried out by Austrian observers, who measured tongue variation during the period 1897-1914 (Fritzsch, 1898, 1899, 1902, 1903; Reishauer, 1908; Döhler, 1917). From 1923 onwards the measurements were performed by Italian observers on behalf of the Comitato Glaciologico Italiano (CGI, 19141977 and 1978-2012). Length change recording consisted of repeated tape readings of the distance between the glacier 

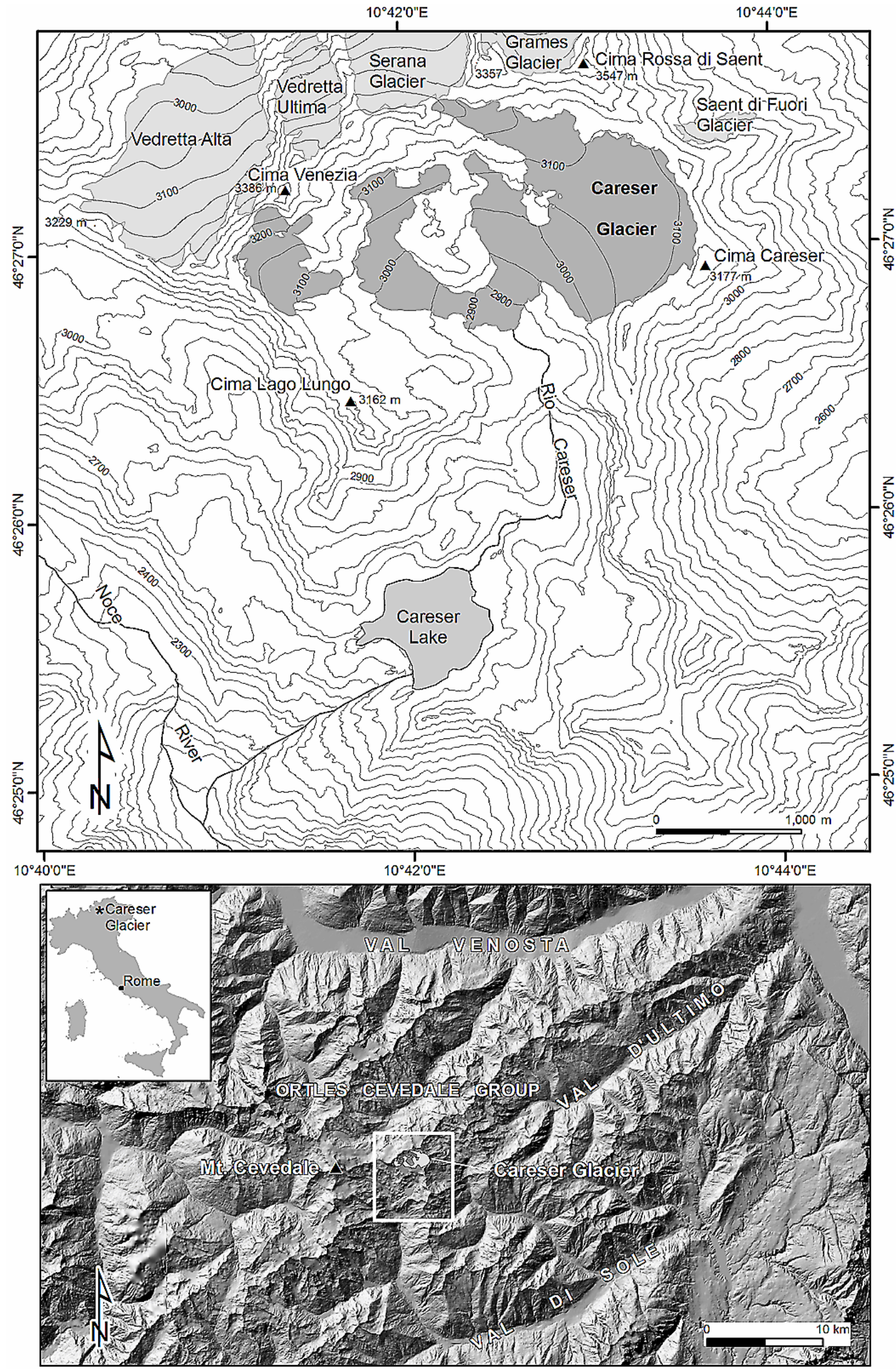

Fig. 1. Geographic setting of the Careser Glacier (2006 surface topography). 
margin and landmarks on the glacier forefield (generally painted boulders). After the 1980s, length variations were assessed via remote sensing (i.e. orthophotos and satellite imagery).

A cumulative length change curve was calculated from the available measurements. Front positions were checked by identifying the lower margin of the glacier on the ground, as visible in old photographs (e.g. Fig. 2), and marking it with a portable GPS (Garmin eTrex Vista with EGNOS differential correction). Other constraints were obtained from existing topographic maps (see the following section); these reference points were required in order to verify the observation series, because in most cases the landmarks were no longer recognisable on the ground. This latter problem was also frequently encountered by the observers who restarted observation after temporary interruptions, preventing linkage with previous measurements. The above checks and calculations were performed using the ESRI software ArcGIS 10.1, with a high-resolution orthophoto (Immagini TerraItaly ${ }^{\mathrm{TM}}$ ${ }^{\circledR}$ Blom CGR S.P.A. - Parma www.terraitaly.it) and a digital terrain model (DTM) acquired in 2006 (Table 1) employed as a background. The estimated accuracy of the determined annual and cumulative length changes is around $\pm 20 \mathrm{~m}$.

\subsection{Topographic surveys}

Calculations of glacier area and volume changes were performed using all available topographic surveys, with the main characteristics of the existing data set presented in Table 1 . Whereas the first topographic survey of the glacier was carried out in 1933 using terrestrial photogrammetry techniques (Desio and Pisa, 1934), subsequent surveys (1959, 1969, 1980, 1990 and 2000) have employed aerial photogrammetry, and the latest in 2006 was acquired via an airborne laser scanner (lidar). All the surveys were carried out at the end of the ablation season, in September or early October, with the exception of the 1933 survey which was performed on 20 August. Maps constructed before 1933 were not used in the present study, because the glacier margins are reported with too little accuracy and because no elevation data are provided over the glacier.

The oldest surveys were available in paper or digital (scanned) form, while the original aerial photos were not available. The 2006 flight was available as a high-resolution orthophoto $(0.5 \mathrm{~m} \times 0.5 \mathrm{~m})$ and a lidar DTM (cell size $2 \mathrm{~m} \times 2 \mathrm{~m}$ ). After scanning (if needed) and georeferencing the oldest maps using the technical provincial map of the province of Trento as a reference, the glacier margins, elevation points and elevation contours were digitised manually. Finally, a DTM with a cell size of $10 \mathrm{~m} \times 10 \mathrm{~m}$ was interpolated from the digitised vector data for each survey date, and the 2006 lidar DTM was resampled to $10 \mathrm{~m} \times 10 \mathrm{~m}$. The entire procedure was performed in the ESRI software ArcGIS 10.1, using the UTM-WGS84 (Universal Transverse Merca-
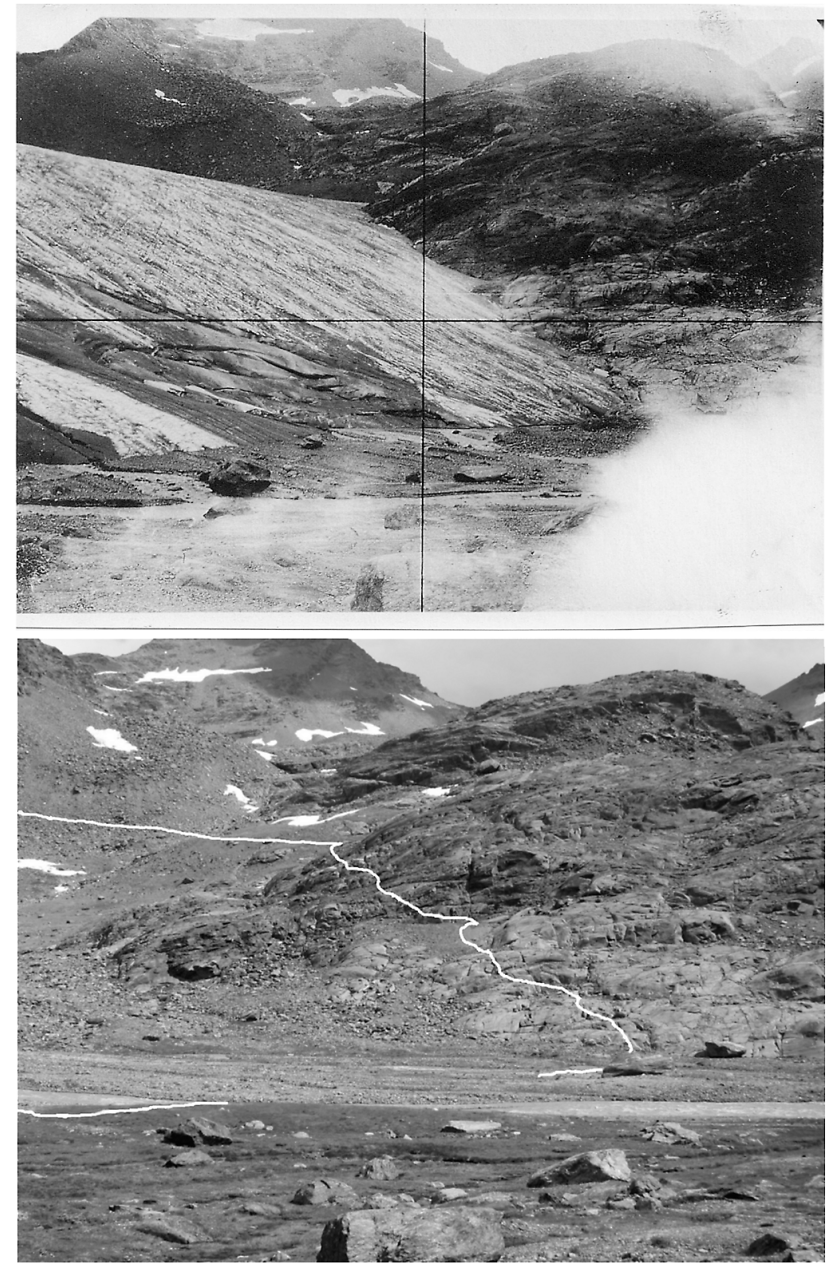

Fig. 2. Example of front position checking by identifying the glacier margin in the ground, as visible in old photographs (upper photo taken on 24 August 1923 (Desio, 1967), lower photo taken on 20 July 2010).

tor, zone 32, World Geodetic System 1984 datum) coordinate system.

The resulting DTMs and polygons of glacierised areas were used to calculate glacier area and volume changes taking place during the period from 1933 to 2006, while the Landsat image of 16 September 2012 (path 193, row 28; downloaded from http://glovis.usgs.gov) was employed to update the perimeter of the glacier, which had split into separate units over the last 6 yr (2006-2012). Finally, the geodetic mass balance rate was calculated from the total volume change $\Delta V\left(\mathrm{~m}^{3}\right)$ occurring between two consecutive survey dates, as follows:

$\Delta V=\bar{\Delta} z \cdot A_{\max }$,

where $\overline{\Delta z}$ is the average elevation change between the two DTMs over the largest area $\left(A_{\max }\right)$ of the glacier in the two survey dates. The area-averaged net geodetic mass balance 
Table 1. Characteristics of the topographic surveys available for the calculation of area and volume changes of Careser Glacier. RMSE and mean error refer to the 2006 DTM.

\begin{tabular}{|c|c|c|c|c|c|c|c|}
\hline $\begin{array}{l}\text { Survey } \\
\text { year }\end{array}$ & Method & $\begin{array}{l}\text { Available } \\
\text { form }\end{array}$ & $\begin{array}{l}\text { Contour } \\
\text { Interval } \\
\text { (m) }\end{array}$ & $\begin{array}{l}\text { Map } \\
\text { scale }\end{array}$ & $\begin{array}{l}\text { Institution } \\
\text { (surveyed by) }\end{array}$ & RMSE & $\begin{array}{r}\text { Mean } \\
\text { error }\end{array}$ \\
\hline 1933 & $\begin{array}{l}\text { Terrestrial } \\
\text { photogrammetry }\end{array}$ & $\begin{array}{l}\text { Paper } \\
\text { map }\end{array}$ & 25 & $1: 8333$ & $\begin{array}{l}\text { Ufficio Idrografico del } \\
\text { Magistrato alle Acque - } \\
\text { Istituto Geografico Militare }\end{array}$ & $9.1 \mathrm{~m}$ & $0.9 \mathrm{~m}$ \\
\hline 1959 & $\begin{array}{l}\text { Aerial } \\
\text { photogrammetry }\end{array}$ & $\begin{array}{l}\text { Paper } \\
\text { map }\end{array}$ & 25 & $1: 25000$ & $\begin{array}{l}\text { Istituto Geografico } \\
\text { Militare }\end{array}$ & $4.1 \mathrm{~m}$ & $0.5 \mathrm{~m}$ \\
\hline 1969 & $\begin{array}{l}\text { Aerial } \\
\text { photogrammetry }\end{array}$ & $\begin{array}{l}\text { Paper } \\
\text { map }\end{array}$ & 5 & $1: 5000$ & $\begin{array}{l}\text { Comitato Glaciologico } \\
\text { Italiano - ENEL (IRTA) }\end{array}$ & $2.5 \mathrm{~m}$ & $0.9 \mathrm{~m}$ \\
\hline 1980 & $\begin{array}{l}\text { Aerial } \\
\text { photogrammetry }\end{array}$ & $\begin{array}{l}\text { Paper } \\
\text { map }\end{array}$ & 5 & $1: 5000$ & $\begin{array}{l}\text { Comitato Glaciologico } \\
\text { Italiano - ENEL (IRTA) }\end{array}$ & $2.2 \mathrm{~m}$ & $-0.9 \mathrm{~m}$ \\
\hline 1990 & $\begin{array}{l}\text { Aerial } \\
\text { photogrammetry }\end{array}$ & $\begin{array}{l}\text { Digital } \\
\text { map }\end{array}$ & 5 & $1: 5000$ & $\begin{array}{l}\text { Comitato Glaciologico } \\
\text { Italiano - ENEL (SCM) }\end{array}$ & $2.1 \mathrm{~m}$ & $-0.8 \mathrm{~m}$ \\
\hline 2000 & $\begin{array}{l}\text { Aerial } \\
\text { photogrammetry }\end{array}$ & $\begin{array}{l}\text { Digital } \\
\text { map }\end{array}$ & 5 & $1: 5000$ & $\begin{array}{l}\text { Comitato Glaciologico } \\
\text { Italiano - ENEL (SCM) }\end{array}$ & $2.5 \mathrm{~m}$ & $-1.0 \mathrm{~m}$ \\
\hline 2006 & lidar & $\begin{array}{l}2 \times 2 \mathrm{~m} \\
\text { DTM }\end{array}$ & - & - & $\begin{array}{l}\text { Provincia Autonoma di } \\
\text { Trento (CGR) }\end{array}$ & - & \\
\hline
\end{tabular}

rate in metres of water equivalent per year $\left(\mathrm{m}\right.$ w.e. $\left.\mathrm{yr}^{-1}\right)$ was then calculated as

$\dot{M}=\frac{\Delta V \cdot \rho}{\bar{A}} \cdot \Delta t^{-1}$,

where $\rho$ is the mean density and $\bar{A}$ the average of the initial and final areas for the time interval $\Delta t$ (years) between the two topographic surveys. Density assumptions were based on the areal extent of the firn zone, which has been documented by the mass balance measurements since 1967 and by old photographs before 1967. A mean density of $900 \mathrm{~kg} \mathrm{~m}^{-3}$ was used between 1933 and 1959 and between 1991 and 2006, when the firn zone was almost absent, while from 1959 to 1990 (when the firn zone temporarily reformed) the mean density was obtained by a fractional area-weighted mean, assuming $900 \mathrm{~kg} \mathrm{~m}^{-3}$ for the ablation area and $600 \mathrm{~kg} \mathrm{~m}^{-3}$ for the accumulation area (Huss, 2013) and obtaining a weighted mean density of $780 \mathrm{~kg} \mathrm{~m}^{-3}$.

The accuracy of the DTMs derived from the digitised maps was evaluated via direct comparison with the highresolution lidar DTM of 2006 (vertical accuracy $=0.3 \mathrm{~m}$ ), using 50 control points located on flat and stable terrain outside the glacier, resulting in an RMSE of the elevation differences between the DTMs ranging from 2.1 to $9.1 \mathrm{~m}$ and in a mean error ranging from $+0.9 \mathrm{~m}$ to $-1.0 \mathrm{~m}$ (Table 1 ). The mean error was subtracted from the DTMs before calculating the geodetic mass balance rates. The total uncertainty depends on the size of the averaging area and the scale of the spatial correlation of elevation differences among the DTMs (Rolstad et al., 2009). Unfortunately, for most of the available surveys it was impossible to obtain reliable statistics (i.e. the spatial correlation function), given their insufficient coverage outside the glacier. Nevertheless, we can estimate an order of magnitude smaller uncertainty in area-averaged calculations (i.e. 0.2 to $0.9 \mathrm{~m}$ ), based on recent assessments concerning DTMs constructed by same techniques in the OrtlesCevedale and glaciers of a similar size to the Careser (Carturan et al., 2013).

Density assumptions may also introduce uncertainties, particularly during periods of shifting firn line (Haug et al., 2009; Huss, 2013). The range of uncertainty in converting volume changes into mass changes was explored by either setting a mean density of $900 \mathrm{~kg} \mathrm{~m}^{-3}$ for the entire glacier, or $900 \mathrm{~kg} \mathrm{~m}^{-3}$ in the ablation area and $600 \mathrm{~kg} \mathrm{~m}^{-3}$ in the firn zone (Gardelle, 2012; Huss, 2013), obtaining a value of $13 \%$.

\subsection{Direct mass balance measurements}

Careser Glacier mass balance measurements commenced during the hydrological year 1966-1967 and has continued to the present without interruption. This work updates previous data published in Carturan and Seppi (2007), adding mass balance data from 2006 to 2012. Data recording was carried out via the "direct glaciological" method, consisting of in situ measurements of surface level changes at a number of points, multiplied by the near-surface density to obtain depths of water equivalent, before finally being interextrapolated to the entire glacier surface (Østrem and Brugman, 1991; Kaser et al., 2003; Cogley et al., 2011). We emphasise that measurements refer to the surface components of mass balance. This method is prescribed for standardised glacier mass balance data collection by the World Glacier Monitoring Service (WGMS).

For most of the $46 \mathrm{yr}$ of observations, the net annual balance was supplemented with distributed measurements of seasonal mass balance (winter and summer balances). 
Between 1983 and 2002, distributed measurements of winter balances were replaced by "index values", consisting of the measurement of the snow accumulation (as detailed below) on a few representative sites along the glacier, close to its median elevation (Giada and Zanon, 1985a; Zanon, 1992). This method has been shown to be successful for other glaciers (e.g. Rasmussen, 2004; Rasmussen and Andreassen, 2005).

Snow accumulation was measured in the second half of May, just before the beginning of the ablation season, by probing the snow depth and measuring the snow density in snow trenches dug at several locations along the glacier. Until 1983, the position of the sampled points was determined using ablation stakes, which were lengthened during winter for this purpose. Since 2003 a portable GPS has been employed.

Ablation was measured using aluminium stakes drilled into the ice by means of an auger. In order to ensure the reliability of these measurements, the stakes were re-drilled when less than $1 \mathrm{~m}$ was left in the ice. The monitoring network was kept as unchanged as possible. However, logistic constraints and the rapid shrinking of the glacier forced the abandonment of the redundant ablation stakes, which had been in use in the first 2 decades of measurements (up to 38 in 1980, Fig. 6). In the accumulation area, ablation was measured as the difference between the water equivalent of snow accumulated above the previous year's summer surface in May and the water equivalent of residual snow at the end of the ablation season. Even after the separation of the parent glacier into several ice masses, starting in 2005, the mass balance calculations have been performed for considering the glacier as a whole. The area and the hypsometry of the glacier used for mass balance calculations were updated about every $10 \mathrm{yr}$ up to the 1990s, while a more frequent update became necessary in the 2000s (Table 3). Consequently, the reported values are "conventional" (i.e. evolving-surface) mass balances (Elsberg et al., 2001), or more properly a combination of conventional and "reference surface" (i.e. fixed surface geometry) mass balances, as normally occurs in long-term mass balance series (Cogley et al., 2011).

Typical errors reported in the literature regarding individual direct mass balance measurements range from 0.1 to $0.3 \mathrm{~m}$ w.e. $\mathrm{yr}^{-1}$ for snow accumulation and from 0.1 to $0.4 \mathrm{~m}$ w.e. $\mathrm{yr}^{-1}$ for ablation (Cogley and Adams, 1998; Gerbaux et al., 2005; Thibert et al., 2008; Huss et al., 2009). Additional errors stem from the spatial integration procedure and from the glacier hypsometry changing over time (Zemp et al., 2013). The total random error for the Careser Glacier can be estimated to be $0.2 \mathrm{mw}$ we. $\mathrm{yr}^{-1}$. Comparisons of whole-glacier calculations with geodetic surveys, at decadal time intervals, revealed good agreement in the past (maximum difference of $0.1 \mathrm{mw}$.e. $\mathrm{yr}^{-1}$ ), and therefore no adjustments were required (Giada and Zanon, 1985b, 1991 and 2001). In this work a complete re-assessment was carried out of glaciological vs. geodetic mass balance series, including new calculations for the period between 2000 and 2006.

\subsection{Geophysical surveys}

Two surveys were conducted in 2007 and 2008 in order to profile the bedrock under the eastern part of the glacier (Martinelli et al., 2010). Whereas the first ground-penetrating radar (GPR) survey was performed on 25 May 2007 with the glacier completely covered by snow (Becker et al., 2007), the second survey was carried out on 2 September 2008, while bare ice was exposed on the glacier surface. The instrumentation employed consisted of a GSSI SIR-2000 system during the first survey and an IDS DAD $2 \mathrm{CH}-\mathrm{MCH}$ system during the second, both of which were equipped with a $200 \mathrm{MHz}$ monostatic antenna. During the first survey this antenna was pulled in a non-metallic sled ahead of the data collection unit (itself placed in another sled) along routes performed north to south and downhill. During the second survey the antenna was manoeuvred by the operator who also carried the data collection unit. The GPR units were synchronised with a GPS for the georeferencing of the surveyed profiles.

The first GPR survey consisted of 8 sections with a total length of $3.7 \mathrm{~km}$, and the second of 44 sections with a total length of $9.0 \mathrm{~km}$. Depth was measured by converting two-way travel times with a velocity of $0.16-0.17 \mathrm{~m} \mathrm{~ns}^{-1}$, as determined by analysis of the hyperbola diffraction due to crevasses or debris embedded in the ice. An error of approximately $0.005 \mathrm{~m} \mathrm{~ns}^{-1}(\sim 3 \%)$ can be estimated for the radar wave velocity, which results in a maximum error of $2.5 \mathrm{~m}$ for the ice depth detected on Careser Glacier (Sect. 4.3). The comparison between the profiles performed with the two systems generally shows similar ice thicknesses, with a mean difference of $2 \mathrm{~m}$ at cross-over points, which is of the same order of magnitude as the uncertainty of the method.

The bedrock topography detected by GPR profiling was interpolated to the entire eastern branch of the glacier $\left(1.6 \mathrm{~km}^{2}\right)$ by ordinary kriging. The semivariogram model was selected by cross-validation among the exponential, Gaussian and spherical models, obtaining better results with a spherical anisotropic semivariogram. Calculations were carried out including elevation data from the 2006 lidar DTM (Sect. 3.2) on the glacier margin and in the deglaciated terrain surrounding the area which was surveyed by GPR.

\section{Results}

\subsection{Area and length fluctuations}

During the first few years of direct measurements (1897 to 1899), although the front of the Careser Glacier retreated at a rate of $6.7 \mathrm{~m} \mathrm{yr}^{-1}$, it was still at an elevation of $2630 \mathrm{~m}$ a.s.l., in close proximity to the alluvial plain which was occupied by the artificial Lake Careser from the 1920s onwards (Fig. 1). According to observations, this snout retreat continued in the decade from 1910 to 1920 , showing only a transitory slowdown between 1910 and 1915 (Fig. 3a), while 


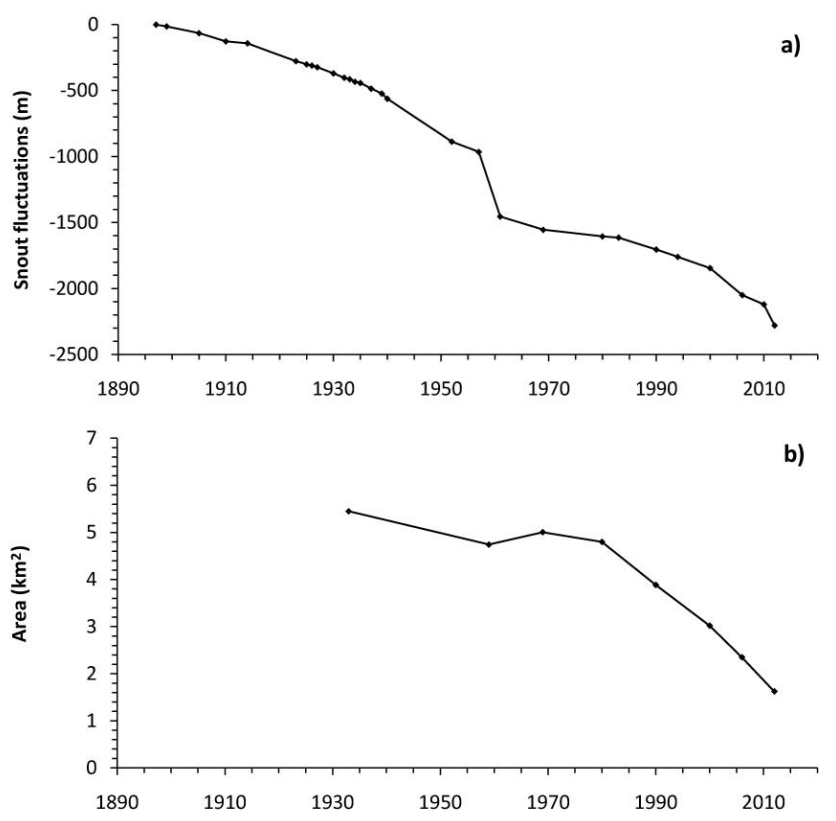

Fig. 3. (a) Snout fluctuations relative to the 1897 position (initial glacier length $=3.8 \mathrm{~km}$ ). (b) Area fluctuations since 1933 .

most other glaciers in the European Alps were observed to re-advance (Hoelzle et al., 2003; Zemp et al., 2008).

At the time of the first photogrammetric survey in 1933 (Fig. 4), the retreating valley tongue was still well-developed and the glacier completely filled the upper basin (Fig. 5). The front was at an elevation of $2650 \mathrm{~m}$ a.s.l. Photographs taken during the survey in August 1933 reveal a nearly flat accumulation area, with some ridge-shaped areas in its northeastern part, likely formed by drifted snow. Few crevasses existed, mainly located in the upper part of the ablation tongue. In many places the glacier reached the surrounding ridges and was connected to neighbouring glaciers to the north (Alta, Ultima, Serana and Grames glaciers) and east (Saent di Fuori and Cima Careser glaciers). Supraglacial moraines were nearly completely absent.

Between 1933 and 1969 the glacier underwent significant changes (Fig. 6), including the frontal retreat accelerating from $11.5 \mathrm{~m} \mathrm{yr}^{-1}$ (between 1897 and 1933) to $23 \mathrm{~m} \mathrm{yr}^{-1}$ (between 1934 and 1957) and the loss of the residual valley tongue, which shrank by $490 \mathrm{~m}$ in the $4 \mathrm{yr}$ from 1957 to 1961 (front elevation rising from 2695 to $2810 \mathrm{~m}$ a.s.l.) due to the outcrop of a topographic step. Significant thinning also took place in the upper part of the glacier, leading to the enlargement of the existing rock outcrops and the formation of a nunatak at the centre of the accumulation area in the period from 1959 to 1969. Although the upper margin of the glacier exhibited no appreciable marginal recession in this time span, most of the neighbouring glaciers detached from the Careser, with the only exceptions being the Serana and Grames glaciers.



Fig. 4. The topographic map derived from the first terrestrial photogrammetric survey of the Careser Glacier, in August 1933 (Desio and Pisa, 1934).

During the following $10 \mathrm{yr}$ from 1970 to 1980 , while the shape of the glacier remained almost unchanged (Fig. 6), the snout continued to retreat, albeit slowly $\left(4 \mathrm{~m} \mathrm{yr}^{-1}\right.$ on average, Fig. 3a), and its elevation increased from 2850 to $2860 \mathrm{~m}$ a.s.l.. Thinning continued and widespread emergence of the bedrock took place in the middle and lower portions of the glacier. Similar to the observations recorded in the 1920s, this behaviour was in contrast to that of the majority of glaciers in the European Alps, which thickened and advanced during the 1970s and early 1980s (Zemp et al., 2008).

Since the 1980s the decay of the glacier has clearly accelerated (Figs. 3 and 6), and its shape has changed rapidly due to the deglaciation of wide areas, even in the upper accumulation zone. Extensive recession of the upper margin of the glacier has occurred along a substantial portion of its perimeter, indicative of accumulation zone thinning. Fragmentation of the residual ice mass started in 2005, with the detachment of the western portion; further rapid disintegration took place in the following years, mostly in the central and western parts of the glacier where the remaining (thin) dead-ice patches are subject to rapid melt and collapse. The south-eastern section has exhibited less impressive changes, maintaining its shape and undergoing a minor retreat of its upper margin.

The total area of Careser Glacier decreased from $5.45 \mathrm{~km}^{2}$ in 1933 to $1.63 \mathrm{~km}^{2}$ in 2012, with the loss of $3.82 \mathrm{~km}^{2}$ representing $70 \%$ of the 1933 area. The area loss rate has also been far higher in the last 3 decades $\left(0.1 \mathrm{~km}^{2} \mathrm{yr}^{-1}\right.$, i.e. $-2 \%$ of the 1980 area per year) than between 1933 and $1959\left(0.03 \mathrm{~km}^{2} \mathrm{yr}^{-1}\right.$, i.e. $-0.5 \%$ of the 1933 area per year $)$, 


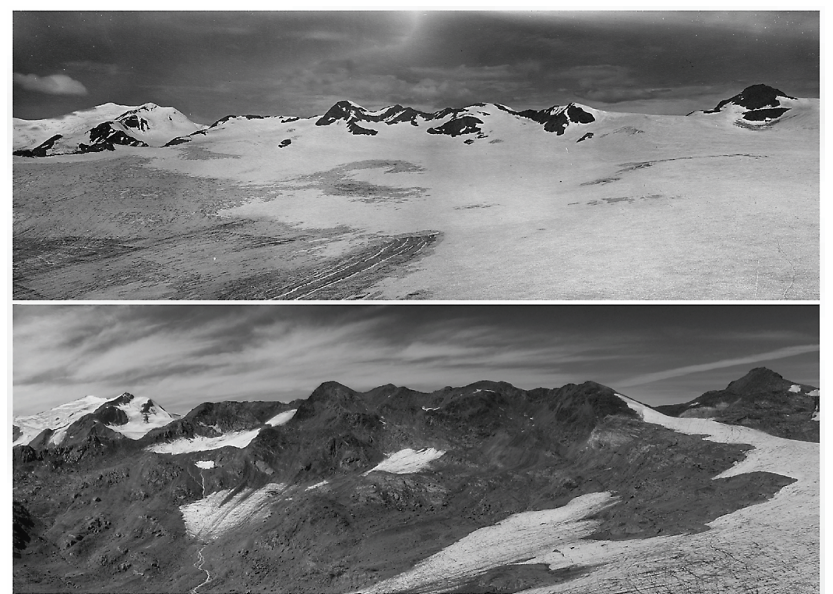

Fig. 5. Photographic comparison of the Careser Glacier in August 1933 (above, courtesy of Comitato Glaciologico Italiano) and on 28 August 2012 (below, photo L. Carturan).

with the rate further accelerating in the $12 \mathrm{yr}$ since 2000 to $0.12 \mathrm{~km}^{2} \mathrm{yr}^{-1}$.

\subsection{Elevation change and mass balance}

The available DTMs reveal that the glacier experienced thinning for most of the period between 1933 and 2006 (Fig. 7), with the only phase of temporary thickening taking place in the upper part of the glacier during the 1960s, when a small areal increase was also observed (Fig. 3b). After 1980, thinning became widespread and strongly accelerated, resulting in bedrock emergence, separation of dead-ice patches and fragmentation. Cumulative elevation changes between 1933 and 2006 amount to an average of $-49 \mathrm{~m}$, reaching peak values of $-122 \mathrm{~m}$ (Fig. 7). The cumulative volume change was $-261 \times 10^{6} \mathrm{~m}^{3}$.

The geodetic and direct mass balance results (Fig. 8) correlate very well for the period with overlap (1969 to 2006). The mean difference among direct and geodetic estimates was $+0.04 \mathrm{~m}$ w.e. $\mathrm{yr}^{-1}$ between 1969 and $1980,-0.09 \mathrm{mw}^{-e .} \mathrm{yr}^{-1}$ between 1980 and 1990, +0.02 mw.e. $\mathrm{yr}^{-1}$ between 1990 and 2000 and $-0.09 \mathrm{~m}$ w.e. $\mathrm{yr}^{-1}$ between 2000 and 2006. The difference between the cumulative direct and the geodetic balances over the common period was $-1.9 \mathrm{~m}$ w.e. The volume change from 1969 to 2006 was $-153 \times 10^{6} \mathrm{~m}^{3}$ according to the geodetic method and $-155 \times 10^{6} \mathrm{~m}^{3}$ according to the direct method. The data series indicates long-term imbalance conditions prevalent from 1933 to 1959 and from 1980 to 2012; between 1960 and 1980 the mass balance was closer to equilibrium (average geodetic mass balance rate of $-0.2 \mathrm{mw}$.e. $\mathrm{yr}^{-1}$ ). The average geodetic mass loss rate between 1981 and $2006\left(-1.3 \mathrm{~m}\right.$ w.e. $\left.\mathrm{yr}^{-1}\right)$ was much higher than that recorded between 1933 and 1959 ( $-0.7 \mathrm{mw}$ w.e. $\left.\mathrm{yr}^{-1}\right)$, with the mean geodetic mass
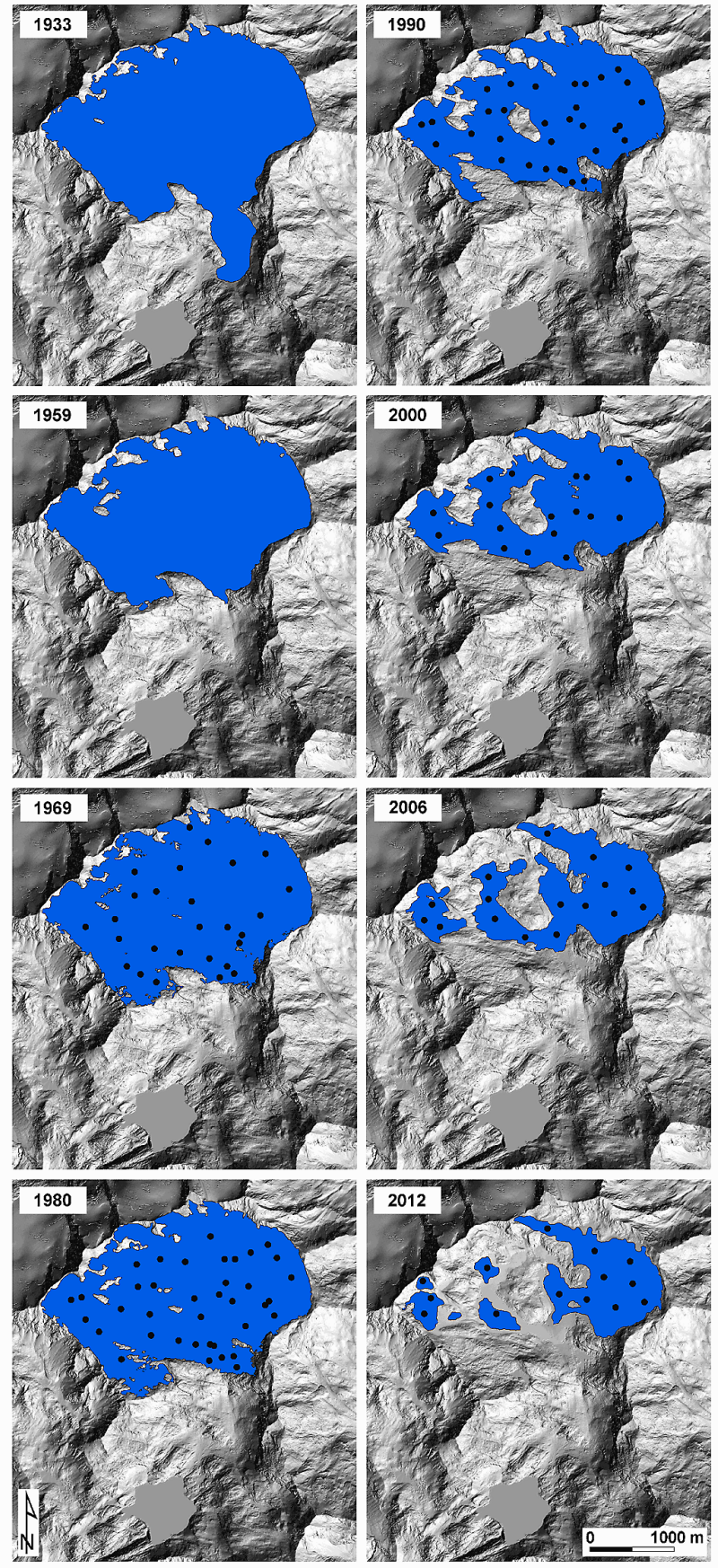

Fig. 6. Extent of the Careser Glacier in eight different epochs from 1933 to 2012. The black dots represent the location of ablation stakes.

balance rate for the entire period from 1933 to 2006 being $-0.8 \mathrm{~m}$ w.e. $\mathrm{yr}^{-1}$.

No observations were made regarding equilibrium line altitude (ELA) and accumulation area ratio (AAR) prior to the initiation of direct mass balance measurements in 1967, but the firn zone was almost completely absent in the 1940s 


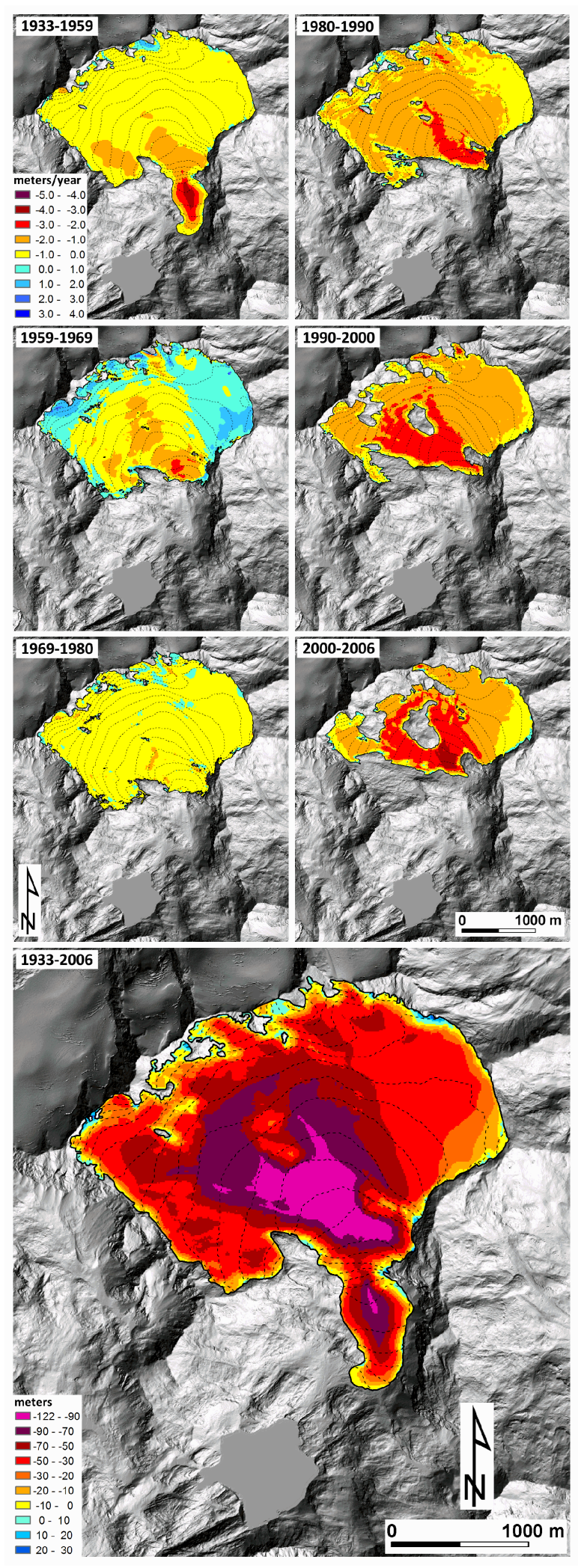

Fig. 7. Mean annual elevation change in six periods (smaller pictures) and cumulated elevation change from 1933 to 2006 (larger picture).
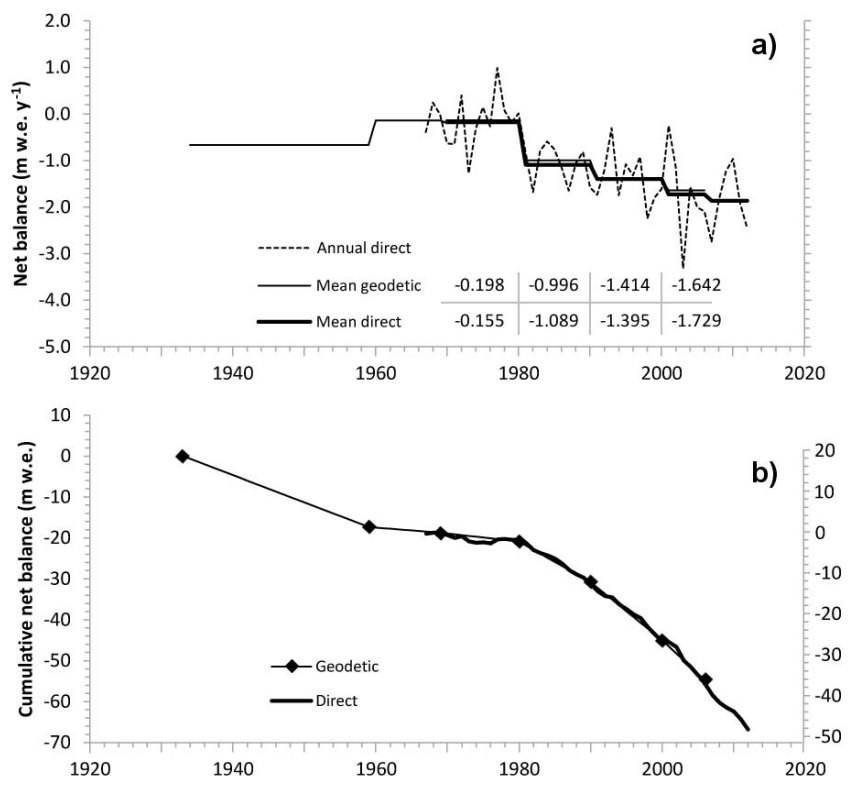

Fig. 8. Annual (a) and cumulative (b) net balance of the Careser Glacier, calculated by the geodetic and direct methods, ending in 2006 and in 2012 respectively. In the lower diagram the geodetic curve has zero value when it begins, and the direct curve (secondary $y$ axis) has been plotted so that it matches the geodetic curve in 1969.

and 1950s, as can be observed in old photographs. A mean ELA value of $3100 \mathrm{~m}$ was measured between 1967 and 1980 (mean AAR $=0.43$ ), while on the contrary the ELA was higher than the maximum elevation of the glacier (which fluctuated between 3280 and $3348 \mathrm{~m}$ ) in the following $32 \mathrm{yr}$, with few exceptions (Table 3 ).

The spatial distribution of the mean annual mass balance during the last decade (Fig. 9) reflects the spatial distribution of the elevation changes resulting from DTM differencing (Fig. 7). Whereas the net ablation in the lower central part of the glacier is currently very rapid and locally exceeds $3 \mathrm{~m}$ w.e. $\mathrm{yr}^{-1}$, a less negative net balance $\left(\sim-1 \mathrm{~m}\right.$ w.e. $\mathrm{yr}^{-1}$ on average) is observed where high snow accumulation combines with low summer ablation (i.e. in the western and south-eastern parts, mainly due to higher elevation and/or lower radiation input). The north-eastern area of the glacier, although at high elevation, has a low snow accumulation as a result of wind scouring and therefore melts rapidly.

\subsection{Ice thickness distribution and bedrock morphology}

The good spatial coverage provided by the GPR profiles obtained in 2007 and 2008 enabled accurate description of the bedrock morphology underneath the eastern branch of the glacier (Fig. 10). The NW-SE profile displayed in Figure 10 reveals a fairly distinct bedrock signature, with no significant radar reflectors between the surface and the bed of the ice body. Moreover, the bedrock appears as a unique reflection, 




Fig. 9. Spatial distribution of the mean annual (direct) mass balance in the decade from 2003 to 2012.

suggesting a sharp transition from ice to rock with negligible debris layers at the base. This profile exemplifies the conditions across most of the surveyed area, with minor exceptions in the upper section and close to the front of the glacier where internal reflections, just above the bedrock, indicate the presence of debris layers.

The thickness of the eastern branch of the glacier, calculated as the difference between the DTM of the glacier surface in October 2006 and that of the bedrock (Fig. 11a), ranged from 0 to $88 \mathrm{~m}$ (Fig. 11b), averaging $27.5 \mathrm{~m}$. The calculated bedrock topography has a fairly regular slope, but becomes steeper towards the ridge which currently bounds the glacier to the south-east. There is a confined area where the glacier reaches its maximum thickness, with the floor lying at $2980-3000 \mathrm{~m}$ a.s.l.

The volume of the eastern part of the glacier in 2006 was $45 \times 10^{6} \mathrm{~m}^{3}$. Although geophysical data were not available for the western part, by combining information obtained from mass balance measurements, changes in extent and field evidence for the residual ice patches (e.g. collapse structures and new rock outcrops), an average thickness of $\sim 20 \mathrm{~m}$ in 2006 can be estimated for this area, indicating a total glacier volume of $59 \times 10^{6} \mathrm{~m}^{3}$. According to this estimate, the cumulative volume loss in $2006\left(261 \times 10^{6} \mathrm{~m}^{3}\right)$ represents $82 \%$ of the initial glacier volume in $1933\left(320 \times 10^{6} \mathrm{~m}^{3}\right)$.

\section{Discussion}

During the field surveys, a nearly complete absence of frontal moraine ridges was observed in the proglacial area between the current front of the glacier and the landforms (trimlines and small moraines) outlining the maximum extent of the glacier during the Holocene. Even though the very scarce debris entrainment due to the small height difference between the glacier surface and the surrounding summits has likely been a cause of this lack of morainic deposits, this geomorphological evidence provides further confirmation of the reconstructed snout fluctuations of the Careser Glacier
(Fig. 3a), which have shown no re-advances since the beginning of direct observations.

The continuous retreat of the front of the Careser Glacier since 1897 differs from the behaviour of most other glaciers in the Ortles-Cevedale group, many of which exhibited temporary re-advances during the periods from 1910 to 1920 and from 1970 to 1980 (Desio, 1967; CGI, 1914-1977 and 19782012). The La Mare glacier ( $5 \mathrm{~km}$ west of Careser), for example, advanced by $164 \mathrm{~m}$ between 1914 and 1923, and by 323 m between 1963 and 1986 .

In the context of the European Alps, the response of the Careser Glacier is typical of flat glaciers (mean slope $<15^{\circ}$ ), being characterised by a constant retreat, or by weak fluctuations with small amplitudes superimposed on a clear overall retreat, since the beginning of measurements (Hoelze et al., 2003). Similarly, Pelto and Hedlund (2001) highlighted a group of glaciers in the North Cascades, Washington, USA, that did not advance during the 20th century, characterized by low slopes, low crevassing, low terminus velocity and low mean accumulation rate. The significant change in glacier geometry likely affected its response during the last century. Between the 1910s and 1920s, the Careser Glacier was still a glacier évacuateur (i.e. a dynamic glacier with ice flow from the accumulation zone to the ablation zone; Lliboutry, 1965), with a length of $3.5 \mathrm{~km}$, a surface velocity of $10.2 \mathrm{~m} \mathrm{yr}^{-1}$ in its valley tongue (Desio, 1967) and the front reaching a minimum elevation of 2645 m a.s.l. By the 1970 $1980 \mathrm{~s}$, the glacier was $2.2 \mathrm{~km}$ in length, its minimum elevation was $2855 \mathrm{~m}$ a.s.l. and it was becoming a glacier réservoir (i.e. static and essentially stagnant) with very low surface velocities (maximum speed of $2 \mathrm{~m} \mathrm{yr}^{-1}$ between 1968 and 1970; Forieri et al., 1999). Consequently, the dynamic response of the glacier during different periods of the time interval investigated (1897-2012) cannot be compared, for example, in terms of how the mass balance changes triggered the observed displacement of the front, especially during the last few decades when stationary thinning and downwasting replaced "active retreat" (Small, 1995).

The good match between the direct and geodetic mass balance series for the period between 1969 and 2006 confirms the results of previous studies (Giada and Zanon, 1985b, 1991 and 2001), with the absence of major deviations. According to Zemp et al. (2013), the cumulative glaciological balance is not statistically different from the geodetic balance, with a $95 \%$ confidence level, and does not require calibration over the reanalysed period (1969-2006).

The long-term (geodetic) mass balance rate of the Careser Glacier between 1933 and $2006\left(-0.8 \mathrm{mw}\right.$.e. $\left.\mathrm{yr}^{-1}\right)$ is far more negative than the secular average mass balance calculated from length change data for the Swiss and eastern Alps since 1900 ( -0.1 to $-0.3 \mathrm{~m}$ w.e. $\mathrm{yr}^{-1}$, Hoelzle et al., 2003). Similar values of mass balance (i.e. $-0.3 \mathrm{~m}$ w.e. $\mathrm{yr}^{-1}$ from 1900 to 2010 , and $-0.4 \mathrm{mw}$ w.e. $\mathrm{yr}^{-1}$ from 1930 to 2011) were obtained for all glaciers in the European Alps by Huss (2012), who extrapolated mass balance data via 

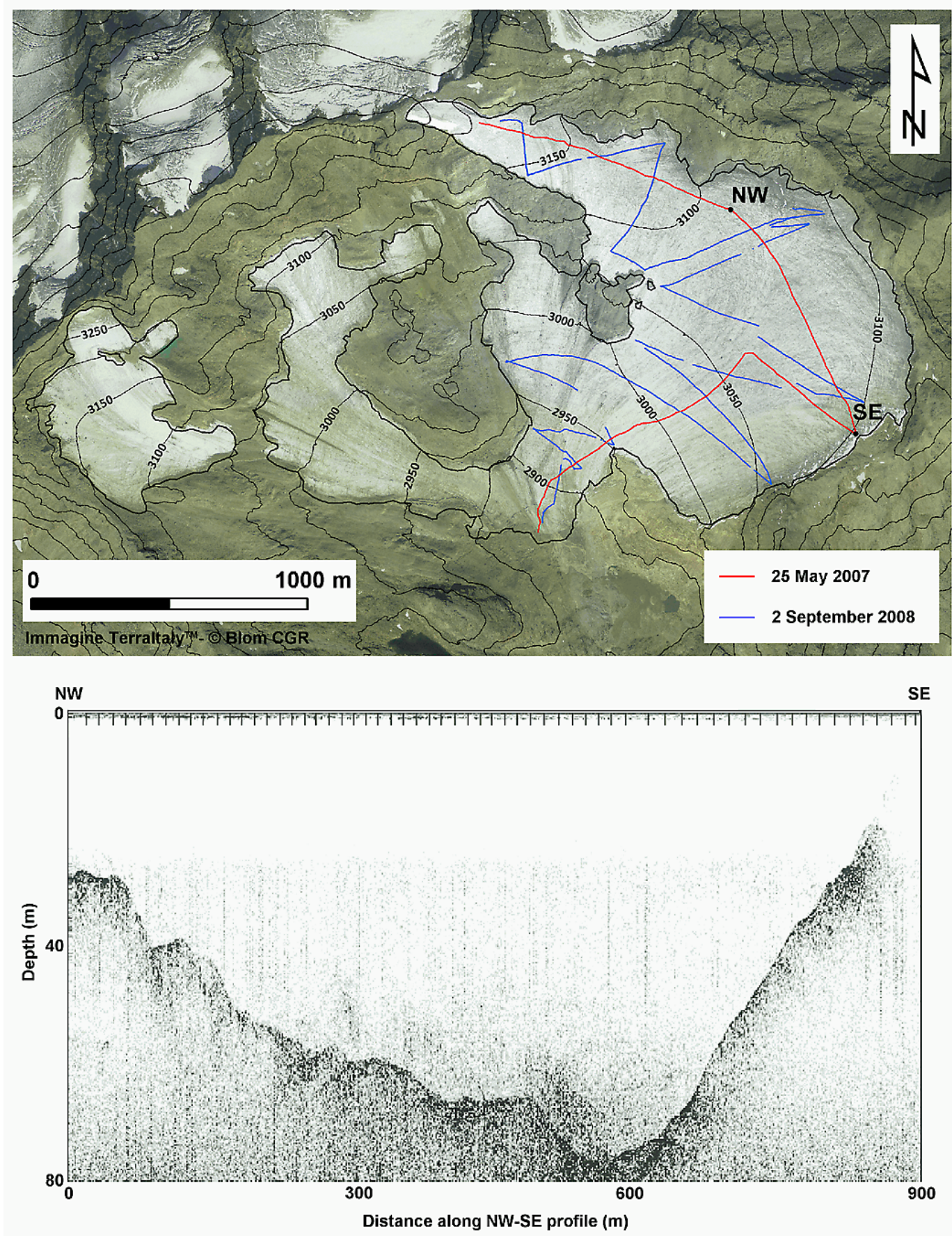

Fig. 10. Spatial coverage of the GPR profiles performed in the eastern part of the Careser Glacier in 2007 and in 2008 (upper picture). In the lower picture an example of unmigrated GPR profile for the section NW-SE is reported.

the use of a multiple regression describing glacier geometry. Direct mass balance results for the last 3 decades on the Careser Glacier have confirmed its higher degree of imbalance $\left(-1.5 \mathrm{~m}\right.$ w.e. $\mathrm{yr}^{-1}$ on average) with respect to a representative sample of Alpine glaciers $\left(-0.8 \mathrm{~m}\right.$ w.e. $\mathrm{yr}^{-1}$ on average, for St. Sorlin, Sarennes, Silvretta, Gries, Sonnblickkees, Vernagtferner, Kesselwandferner, and Hintereisferner;
Zemp et al., 2005; WGMS, 2009). The peculiar behaviour of the Careser Glacier was also highlighted in a recent work which analysed the shrinking of glaciers in the OrtlesCevedale group over the last 3 decades (Carturan et al., 2013); during this period, the area and mass loss rates of the Careser were more than twice the mean of the other 111 glaciers in this mountain group, and the difference from their 

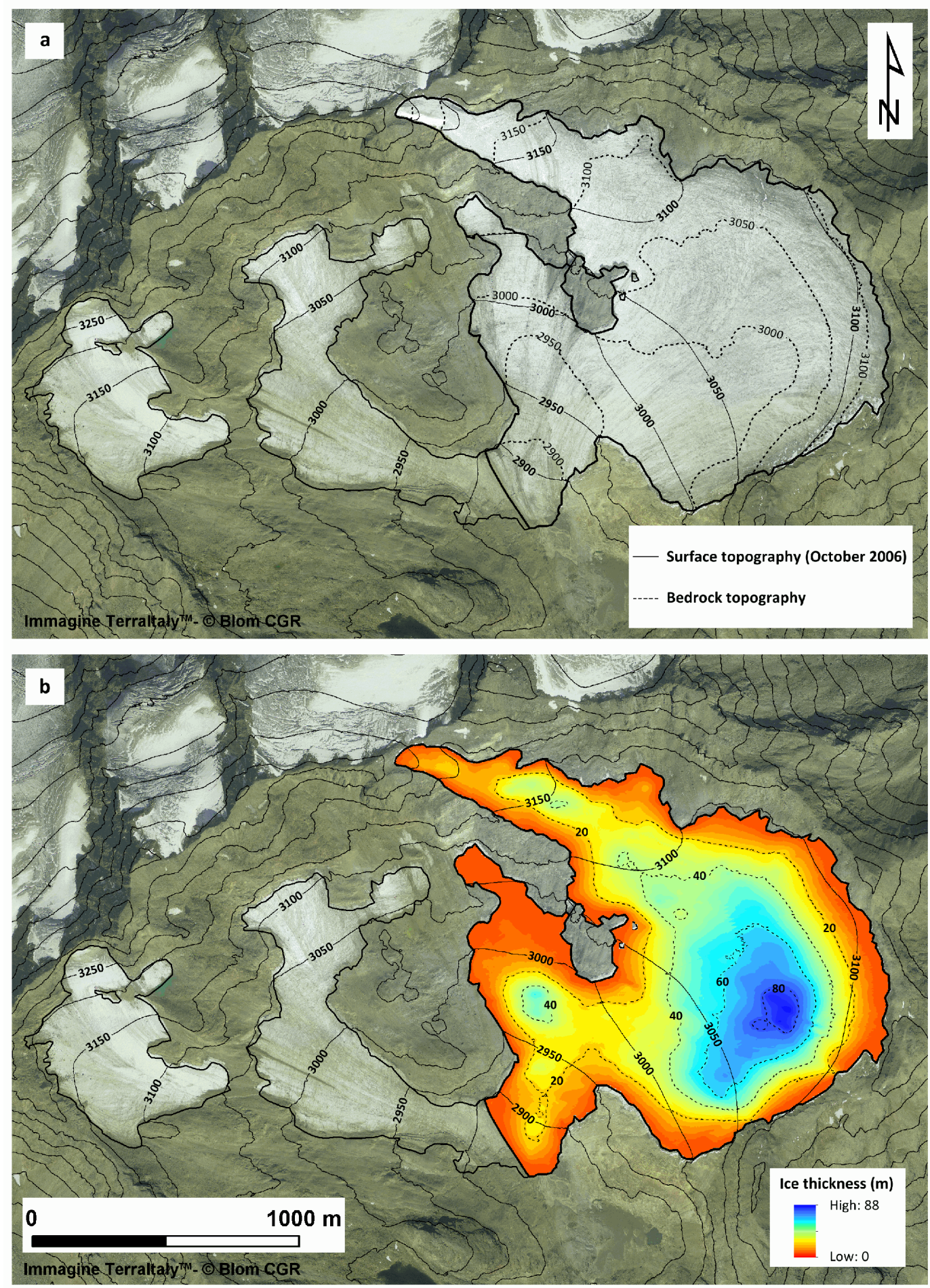

Fig. 11. Results of GPR profiling in the eastern part of the Careser Glacier: (a) surface topography in 2006 and underlying bedrock topography and (b) spatial distribution of the residual ice thickness in 2006.

mean was about three times the standard deviation of the same set of glaciers.

The peculiar response of the Careser to climate changes is likely due to its geometry, a characteristic which typically influences the climate sensitivity and volume response time of individual glaciers (Oerlemans, 2007). Much of the catchment hosting the former accumulation area of the glacier lies between 2950 and 3150 ma.s.1.; small changes in the ELA 
therefore have a large impact on this catchment (Oerlemans, 2001; Benn and Evans, 2010). Indeed, fluctuations in the ELA of only $200 \mathrm{~m}$, if sustained for enough time, may lead to the complete glacierisation or deglaciation of the catchment and to the development or disappearance of the large valley tongue which existed in the past and which disappeared during the 20th century (GNGFG-CNR, 1986; Pulejo, 1998). According to Jóhannesson et al. (1989), the volume response time (years) is given by

$\tau=\frac{H}{-b_{\mathrm{t}}}$,

where $H$ is a characteristic ice thickness (m), usually taken at the equilibrium line where ice depths are near maximum, and $b_{\mathrm{t}}$ is the mass balance rate at the glacier tongue ( $\mathrm{m}$ w.e. ${\mathrm{r}^{-1}}^{-1}$. $H$ and $b_{\mathrm{t}}$ have been calculated from the geometry of the Careser Glacier in 1933 and from the average mass balance gradient in the period of direct mass balance measurements (5.3 mm w.e. $\left.\mathrm{m}^{-1} \mathrm{yr}^{-1}\right)$, obtaining a response time of $35 \mathrm{yr}$. This volume response time is based on the assumption of a glacier of unit or uniform width with all area changes at the terminus. According to Raper and Braithwaite (2009), it should therefore be multiplied by a factor of $\sim 2.9$, in order to account for the mass-balance-elevation feedback associated with elevation changes of the glacier surface due to thinning or thickening in both accumulation and ablation areas. The numerical factor was derived from a set of 5291 glaciers in the European Alps and is applicable to glaciers of different sizes. The tendency of Eq. (3) to underestimate the response time, when the slope of the glacier is small and the altitudemass balance feedback becomes important, as it does for the Careser Glacier, was also acknowledged by Oerlemans (1997 and 2001) and by Harrison and Others (2003). Based on these considerations, a secular response time can be estimated for the Careser Glacier. As reported by Hoelzle et al., (2003), flat (and/or large) glaciers have a comparatively higher thickness and are therefore subject to larger ice losses compared to small (and/or steep) glaciers, where the bedrock is reached relatively quickly. In other words, the Careser Glacier is still dissipating the thick ice mass accumulated during the Little Ice Age ( 1570-1900 AD; Matthews and Briffa, 2005).

The average mass loss rate of the glacier for the last 3 decades is about twice that for the period from 1933 to 1959 , with mass balance also becoming increasingly negative from the 1980s to the 2000s (Fig. 8). Although a longterm non-zero balance is typically the expression of sustained climatic forcing (WGMS, 2011), feedback mechanisms likely modulated the response of the Careser Glacier. Comparison between present and past mass balance values must therefore take such feedbacks into account; in particular, a large portion of the reaction to climate change may be hidden in geometric adjustments (e.g. Elsberg et al., 2001; Paul, 2010). The main processes involved are (i) terminus retreat and decrease of glacier area by the melt-out of sectors subject to higher net ablation, (ii) lowering of albedo, (iii) thinning and surface lowering (mass-balance-elevation feedback), and (iv) increased thermal emission from expanding patches of ice-free terrain. Hitherto, the last three (positive) feedbacks likely overcame the first one (negative), and the decrease of glacier area was mainly the result of downwasting rather than reflecting dynamic adjustment. Indeed, a comparison of glacier hypsometry in 1933 and 2006 (Fig. 12 and Table 2) reveals a lack of adjustment of the glacier to climate change, since the area losses were proportionally larger at higher elevations. This led to a decrease in the median elevation from 3101 to 3069 m a.s.l., rather than to an increase as would be expected for a "dynamically" adjusting glacier, indicating that the positive mass balance feedback due to thinning at least partly compensates the negative feedback due to retreat (Huss et al., 2012). The massbalance-elevation feedback can be estimated from the mass balance gradient and from the observed change in mean glacier elevation, resulting in an average mass balance perturbation of $-0.13 \mathrm{~m}$ w.e. $\mathrm{yr}^{-1}$, with maximum values reaching $-0.48 \mathrm{~m}$ w.e. $\mathrm{yr}^{-1}$ in the lower part of the current glacier.

The present behaviour of the Careser Glacier leaves no doubt as to the certainty of its complete disappearance in the next few decades with either continuation of current climate conditions or additional warming. The ELA was above its maximum elevation for 22 out of $31 \mathrm{yr}$ since 1981, when a regime shift clearly took place. This was also observable in most long-term monitored glaciers in the European Alps (e.g. Sarennes Glacier in France, Thibert et al., 2013; Hintereisferner in Austria, Fisher, 2010; Gries in Switzerland, Funk et al., 1997). The sustained absence of an accumulation area in the last 3 decades is indicative of a strong imbalance and impending extinction of the ice body. Rapid thinning, marginal recession, the emergence of new rock outcrops and fragmentation are taking place not only in the lower part of the glacier, but after 1980 also in the upper half, which should be the accumulation area, indicating an important change from an equilibrium response to a disequilibrium response (Pelto, 2010).

Making the realistic assumption of a complete absence of motion (as demonstrated by recent GPS surveys of the ablation stakes) and negligible basal melt (as suggested by the good correspondence between the direct and geodetic mass balances), the future evolution of the glacier was calculated from the 2006 ice thickness distribution (Fig. 11b) and from the spatial distribution of the average annual mass balance for the last $10 \mathrm{yr}$ (Fig. 9). The average annual mass balance rates for each point of the glacier were converted into annual lowering rates by using ice density, and then multiplied by 14,34 and 54 to calculate the cumulated lowering from 2006 to 2020, 2040 and 2060. The projected future extent of the glacier, with the hypothesis of unchanged climatic conditions and absence of feedbacks, is displayed in Fig. 13. As this figure shows, the westernmost patches would disappear almost completely by 2020 , given the small residual thickness here which can be inferred from field evidence (widespread 
Table 2. Distribution of area vs. elevation on Careser Glacier from 1933 to 2006.

\begin{tabular}{llllllll}
\hline & \multicolumn{7}{c}{ Area $\left(\mathrm{km}^{2}\right)$} \\
\cline { 2 - 8 } Elevation band & 1933 & 1959 & 1969 & 1980 & 1990 & 2000 & 2006 \\
\hline $2650-2700$ & 0.04 & - & - & - & - & - & - \\
$2700-2750$ & 0.06 & - & - & - & - & - & - \\
$2750-2800$ & 0.20 & - & - & - & - & - & - \\
$2800-2850$ & 0.06 & 0.01 & - & - & - & - & - \\
$2850-2900$ & 0.05 & 0.04 & 0.08 & 0.07 & 0.09 & 0.07 & 0.07 \\
$2900-2950$ & 0.09 & 0.19 & 0.22 & 0.22 & 0.20 & 0.21 & 0.13 \\
2950-3000 & 0.33 & 0.36 & 0.40 & 0.39 & 0.37 & 0.36 & 0.33 \\
$3000-3050$ & 0.63 & 0.82 & 0.86 & 0.84 & 0.66 & 0.57 & 0.41 \\
$3050-3100$ & 1.21 & 1.17 & 1.04 & 1.03 & 0.96 & 0.93 & 0.83 \\
$3100-3150$ & 1.55 & 1.30 & 1.43 & 1.32 & 1.04 & 0.60 & 0.37 \\
$3150-3200$ & 0.68 & 0.46 & 0.51 & 0.46 & 0.31 & 0.20 & 0.15 \\
3200-3250 & 0.38 & 0.29 & 0.30 & 0.28 & 0.19 & 0.06 & 0.04 \\
3250-3300 & 0.14 & 0.10 & 0.16 & 0.16 & 0.06 & 0.03 & 0.02 \\
$3300-3350$ & 0.03 & 0.01 & 0.02 & 0.02 & - & - & - \\
\hline Total & 5.45 & 4.74 & 5.00 & 4.80 & 3.88 & 3.02 & 2.35 \\
\hline Minimum elevation & 2655 & 2782 & 2854 & 2858 & 2859 & 2858 & 2865 \\
Maximum elevation & 3345 & 3325 & 3340 & 3348 & 3317 & 3297 & 3280 \\
Mean elevation & 3081 & 3087 & 3089 & 3087 & 3075 & 3059 & 3056 \\
Median elevation & 3101 & 3093 & 3094 & 3092 & 3084 & 3070 & 3069 \\
\hline
\end{tabular}

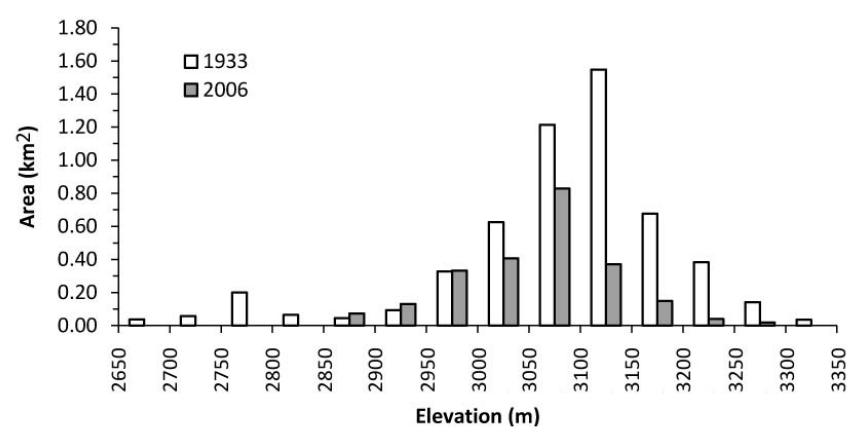

Fig. 12. Hypsography of the Careser Glacier in 1933 and in 2006.

outcrop of bedrock and basal till, bedrock reached at depths $<8 \mathrm{~m}$ during re-positioning of ablation stakes). The larger residual ice body would survive in the eastern part of the catchment, but would shrink to $0.65 \mathrm{~km}^{2}$ by $2020,0.15 \mathrm{~km}^{2}$ by 2040 and almost vanish entirely by 2060 .

Given the peculiar behaviour of the Careser Glacier, and its forthcoming decay, one may expect its representativeness to decrease further in the future, and one may wonder for how many years it still makes sense to continue the measurements. Besides local differences in the magnitude of annual glacier mass balance, a good correlation generally exists for year-to-year variations in mass balance up to distances of several hundreds of kilometres (Letréguilly and Reynaud, 1990; Cogley and Adams, 1998; Pelto, 2008; Fountain et al., 2009). The mass balance of the Careser Glacier in the last 3 decades was indeed significantly correlated with that of several other glaciers in the European Alps (Table 4). Notably, in many cases, the correlation increased and/or became significant in the last decade, and this is somehow conflicting with the expected decrease in the representativeness due to the accelerated decline of the Careser Glacier in the last decade. The observed increase in correlation could be attributable to climatic causes, but glacier dynamics might have played a role as well. On the one hand it is possible that the rapid melt out of areas subject to higher ablation results in an increase of the spatial representativeness of the Careser Glacier. On the other hand it is also plausible that other glaciers in the Alps are experiencing the same processes which occurred earlier on Careser Glacier, i.e. the loss of the snow and firn cover with a corresponding decrease of albedo, the lowering of the surface leading to a positive elevation feedback, and the widespread emergence of bedrock causing fragmentation, now evident on many of the glaciers reported in Table 4 (e.g. glaciological reports, 1881-2011; Thibert et al., 2008; Paul, 2010; WGMS, 2011, 2012 and earlier volumes). A deeper insight into these processes deserves further investigation and field data. It is our opinion that mass balance observations should therefore continue as long as possible, even on glaciers undergoing rapid decay like the Careser Glacier. At the same time, as suggested by the World Glacier Monitoring Service (Zemp et al., 2009), parallel observations should be started on neighbouring larger and higher-reaching glaciers, to replace vanishing long-term mass balance sites. 
Table 3. Careser Glacier mass balance series from 1967 to 2012. Values with asterisks are "index" values (i.e. measurements on few representative points close to the median elevation of the glacier).

\begin{tabular}{|c|c|c|c|c|c|c|c|}
\hline Year & $\begin{array}{r}\text { Specific } \\
\text { winter } \\
\text { balance } \\
(\mathrm{mm} \text { w.e. })\end{array}$ & $\begin{array}{r}\text { Specific } \\
\text { summer } \\
\text { balance } \\
\text { (mm w.e.) }\end{array}$ & $\begin{array}{r}\text { Specific } \\
\text { annual } \\
\text { balance } \\
\text { (mm w.e.) }\end{array}$ & $\begin{array}{r}\text { Equilibrium } \\
\text { line } \\
\text { altitude } \\
(\mathrm{m})\end{array}$ & $\begin{array}{r}\text { Accumulation } \\
\text { area } \\
\text { ratio } \\
(\%)\end{array}$ & $\begin{array}{r}\text { Cumulative } \\
\text { net } \\
\text { balance } \\
\text { (m w.e.) }\end{array}$ & $\left(\mathrm{km}^{2}\right)$ \\
\hline $1966 / 67$ & 1016 & -1402 & -386 & 3165 & 15 & $-0.39 \pm 0.20$ & 4.72 \\
\hline $1967 / 68$ & 788 & -541 & 247 & 3045 & 70 & $-0.14 \pm 0.28$ & 4.70 \\
\hline $1968 / 69$ & 989 & -994 & -5 & 3084 & 53 & $-0.14 \pm 0.35$ & 4.72 \\
\hline $1969 / 70$ & 995 & -1626 & -631 & 3155 & 17 & $-0.78 \pm 0.40$ & 4.68 \\
\hline $1970 / 71$ & 1083 & -1733 & -650 & 3159 & 17 & $-1.43 \pm 0.45$ & 4.68 \\
\hline $1971 / 72$ & 1065 & -665 & 400 & 3014 & 82 & $-1.03 \pm 0.49$ & 4.68 \\
\hline $1972 / 73$ & 602 & -1878 & -1276 & 3251 & 2 & $-2.30 \pm 0.53$ & 4.68 \\
\hline $1973 / 74$ & 995 & -1314 & -319 & 3137 & 25 & $-2.62 \pm 0.57$ & 4.68 \\
\hline $1974 / 75$ & 1152 & -1007 & 145 & 3053 & 67 & $-2.48 \pm 0.60$ & 4.68 \\
\hline $1975 / 76$ & 611 & -879 & -268 & 3200 & 8 & $-2.74 \pm 0.63$ & 4.68 \\
\hline $1976 / 77$ & 1894 & -906 & 988 & 2857 & 98 & $-1.76 \pm 0.66$ & 4.68 \\
\hline $1977 / 78$ & 1204 & -1125 & 79 & 3060 & 63 & $-1.68 \pm 0.69$ & 4.68 \\
\hline $1978 / 79$ & 1103 & -1285 & -182 & 3125 & 32 & $-1.86 \pm 0.72$ & 4.68 \\
\hline $1979 / 80$ & & & 12 & 3083 & 53 & $-1.85 \pm 0.75$ & 4.83 \\
\hline $1980 / 81$ & & & -839 & $>3348$ & 0 & $-2.69 \pm 0.77$ & 4.83 \\
\hline $1981 / 82$ & 684 & -2362 & -1678 & $>3348$ & 0 & $-4.36 \pm 0.80$ & 4.83 \\
\hline $1982 / 83$ & $1400^{*}$ & $-2187^{*}$ & -787 & $>3348$ & 0 & $-5.15 \pm 0.82$ & 4.83 \\
\hline $1983 / 84$ & $990^{*}$ & $-1581^{*}$ & -591 & 3273 & 3 & $-5.74 \pm 0.85$ & 4.83 \\
\hline $1984 / 85$ & $1045^{*}$ & $-1803^{*}$ & -758 & 3279 & 3 & $-6.50 \pm 0.87$ & 4.83 \\
\hline $1985 / 86$ & & & -1138 & $>3348$ & 0 & $-7.64 \pm 0.89$ & 4.83 \\
\hline $1986 / 87$ & & & -1645 & $>3348$ & 0 & $-9.28 \pm 0.92$ & 4.83 \\
\hline $1987 / 88$ & $813^{*}$ & $-1869^{*}$ & -1056 & $>3348$ & 0 & $-10.34 \pm 0.94$ & 4.83 \\
\hline $1988 / 89$ & $777^{*}$ & $-1594^{*}$ & -817 & 3275 & 2 & $-11.16 \pm 0.96$ & 4.83 \\
\hline $1989 / 90$ & $610^{*}$ & $-2188^{*}$ & -1578 & $>3317$ & 0 & $-12.73 \pm 0.98$ & 4.83 \\
\hline 1990/91 & $1020^{*}$ & $-2754^{*}$ & -1734 & $>3317$ & 0 & $-14.47 \pm 1.00$ & 3.86 \\
\hline $1991 / 92$ & $884^{*}$ & $-2083^{*}$ & -1199 & $>3317$ & 0 & $-15.67 \pm 1.02$ & 3.86 \\
\hline $1992 / 93$ & $941^{*}$ & $-1244^{*}$ & -303 & 3148 & 14 & $-15.97 \pm 1.04$ & 3.86 \\
\hline $1993 / 94$ & $1065^{*}$ & $-2808^{*}$ & -1743 & $>3317$ & 0 & $-17.71 \pm 1.06$ & 3.86 \\
\hline $1994 / 95$ & $571^{*}$ & $-1652^{*}$ & -1081 & $>3317$ & 0 & $-18.79 \pm 1.08$ & 3.86 \\
\hline $1995 / 96$ & $598^{*}$ & $-1918^{*}$ & -1320 & $>3317$ & 0 & $-20.11 \pm 1.10$ & 3.86 \\
\hline $1996 / 97$ & $927^{*}$ & $-1847^{*}$ & -920 & 3264 & 2 & $-21.03 \pm 1.11$ & 3.86 \\
\hline $1997 / 98$ & $624^{*}$ & $-2864^{*}$ & -2240 & $>3317$ & 0 & $-23.27 \pm 1.13$ & 3.36 \\
\hline $1998 / 99$ & & & -1800 & $>3317$ & 0 & $-25.07 \pm 1.15$ & 3.36 \\
\hline $1999 / 00$ & & & -1610 & $>3297$ & 0 & $-26.68 \pm 1.17$ & 3.36 \\
\hline $2000 / 01$ & $1800^{*}$ & $-2050^{*}$ & -250 & 3170 & 12 & $-26.93 \pm 1.18$ & 3.36 \\
\hline $2001 / 02$ & & & -1149 & 3250 & 1 & $-28.08 \pm 1.20$ & 2.83 \\
\hline $2002 / 03$ & 1021 & -4338 & -3317 & > 3297 & 0 & $-31.40 \pm 1.22$ & 2.83 \\
\hline $2003 / 04$ & 1069 & -2631 & -1562 & $>3297$ & 0 & $-32.96 \pm 1.23$ & 2.83 \\
\hline $2004 / 05$ & 826 & -2831 & -2005 & $>3297$ & 0 & $-34.97 \pm 1.25$ & 2.83 \\
\hline $2005 / 06$ & 841 & -2934 & -2093 & $>3280$ & 0 & $-37.06 \pm 1.26$ & 2.40 \\
\hline $2006 / 07$ & 381 & -3127 & -2746 & $>3280$ & 0 & $-39.81 \pm 1.28$ & 2.40 \\
\hline $2007 / 08$ & 744 & -2596 & -1851 & $>3280$ & 0 & $-41.66 \pm 1.30$ & 1.93 \\
\hline 2008/09 & 1347 & -2583 & -1235 & 3260 & 1 & $-42.89 \pm 1.31$ & 1.93 \\
\hline $2009 / 10$ & 1054 & -2016 & -962 & 3250 & 9 & $-43.85 \pm 1.33$ & 1.89 \\
\hline $2010 / 11$ & 868 & -2790 & -1922 & $>3280$ & 0 & $-45.78 \pm 1.34$ & 1.89 \\
\hline $2011 / 12$ & 799 & -3259 & -2460 & $>3280$ & 0 & $-48.25 \pm 1.36$ & 1.63 \\
\hline
\end{tabular}




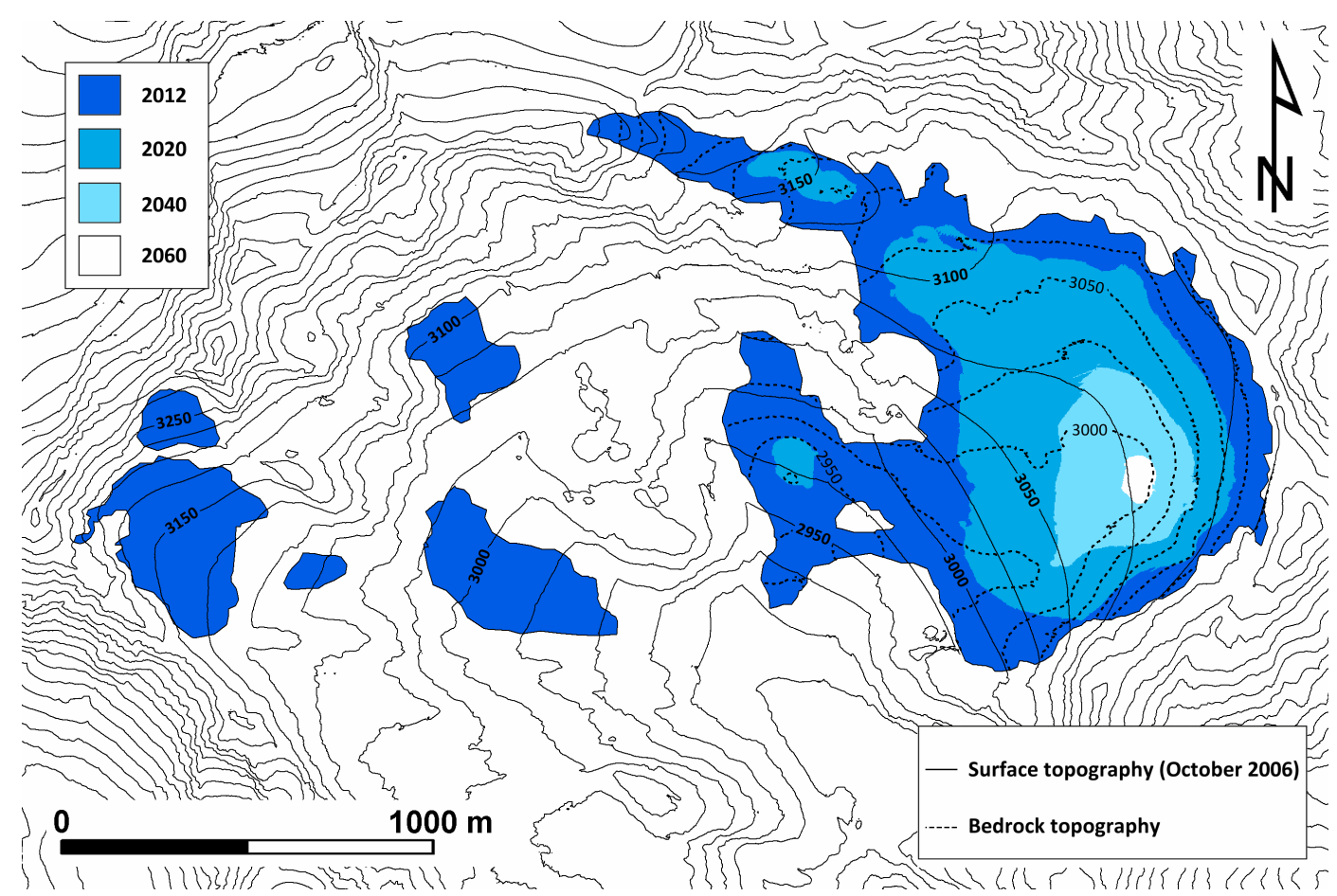

Fig. 13. Current (2012) and future extent of the Careser Glacier, assuming unchanged spatial distribution of the mean annual mass balance compared to the decade from 2003 to 2012 (Fig. 9), and negligible glacier motion.

Table 4. Correlation coefficients calculated from the specific annual balances of Careser Glacier and other 15 glaciers in the Alps in the period from 1981 to 2010. Mass balance data have been taken from Fluctuations of Glaciers (WGMS, 2012 and earlier volumes), except for La Mare glacier (Carturan et al., 2009). Numbers in brackets indicate partial coverage (years) for the examined decades. Correlations which are not significant at the 0.05 level are marked in bold type.

\begin{tabular}{|c|c|c|c|c|c|c|c|c|c|}
\hline & \multicolumn{9}{|c|}{ Italian Alps } \\
\hline & \multicolumn{5}{|c|}{ Ortles-Cevedale group } & \multicolumn{2}{|c|}{ Western Alps } & \multicolumn{2}{|c|}{ Eastern Alps } \\
\hline & $\begin{array}{l}\text { Sfor- } \\
\text { zellina }\end{array}$ & $\begin{array}{l}\text { Fontana } \\
\text { Bianca }\end{array}$ & Lunga & \multicolumn{2}{|c|}{$\begin{array}{l}\text { La } \\
\text { Mare }\end{array}$} & \multicolumn{2}{|l|}{$\begin{array}{l}\text { Ciar- } \\
\text { doney }\end{array}$} & $\begin{array}{l}\text { Pen- } \\
\text { dente }\end{array}$ & $\begin{array}{l}\text { Mala- } \\
\text { valle }\end{array}$ \\
\hline 1981-1990 & $0.75(4)$ & $0.36(5)$ & & & & & & & \\
\hline 1991-2000 & 0.85 & $0.72(9)$ & & & & $0.81(9)$ & & $0.74(5)$ & \\
\hline \multirow[t]{4}{*}{ 2001-2010 } & $0.83(9)$ & 0.97 & $0.78(7)$ & 0.6 & (6) & 0.90 & & 0.87 & $0.81(9)$ \\
\hline & \multicolumn{9}{|c|}{ European Alps - outside Italy } \\
\hline & \multicolumn{2}{|c|}{ France } & \multicolumn{3}{|c|}{ Switzerland } & \multicolumn{4}{|c|}{ Austria } \\
\hline & $\begin{array}{l}\text { Saint } \\
\text { Sorlin }\end{array}$ & Sarennes & Silv & etta & Gries & $\begin{array}{l}\text { Sonn- } \\
\text { blick }\end{array}$ & $\begin{array}{l}\text { Ver- } \\
\text { nagt }\end{array}$ & $\begin{array}{l}\text { Kessel- } \\
\text { wand }\end{array}$ & $\begin{array}{l}\text { Hin- } \\
\text { tereis }\end{array}$ \\
\hline $1981-1990$ & 0.33 & 0.16 & 0.51 & & 0.63 & 0.64 & 0.61 & 0.72 & 0.77 \\
\hline $1991-2000$ & 0.57 & 0.43 & 0.44 & & 0.79 & 0.47 & 0.35 & 0.50 & 0.68 \\
\hline 2001-2010 & 0.73 & 0.59 & 0.80 & & 0.88 & 0.77 & 0.79 & 0.85 & 0.91 \\
\hline
\end{tabular}

\section{Conclusions}

A large body of information available in the form of length change measurements, photographs, topographic maps and a unique series of mass balance measurements for the Italian
Alps was assembled and processed in order to analyse the fluctuations of the Careser Glacier from the commencement of the first direct observations at the end of the 19th century.

The glacier has retreated by $2.3 \mathrm{~km}$ since 1897, without significant interruption, and has lost $70 \%$ of its area. In 2006 
the glacier volume was $82 \%$ smaller than on 1933. Its mass balance was negative for most of the observation period, with a temporary phase of only slightly negative mass balance between 1959 and 1980. The present-day ELA is above the maximum elevation of the glacier, causing increasingly negative mass balance and rapid fragmentation, due to unfavourable climatic conditions reinforced by positive feedbacks.

The behaviour of the glacier is peculiar, displaying far higher mass loss rates both at the regional scale and in the context of the European Alps. Its high climatic sensitivity appears to be mainly attributable to its hypsometry, which causes large variations in the AAR in response to small changes in the ELA. The glacier persists today thanks only to the thick ice mass accumulated during the Little Ice Age; according to the present-day mass balance distribution and residual ice thickness, it will experience further rapid, and ultimately complete, extinction within a few decades, even without additional climatic warming.

The rapid modification of the Careser Glacier and its impending extinction will have important consequences for future monitoring. Indeed, length change measurements are already meaningless for a glaciological or climatological interpretation, due to the observed transition from active retreat to downwasting. Moreover, the climatic interpretation of the mass balance series is rather complex and its spatial representation poor, largely due to the rapid modification and interplay of feedbacks which self-accelerate the glacier decline. Nevertheless, contrary to what was expected, the correlation with other long-term mass balance series in the $\mathrm{Eu}-$ ropean Alps is increasing, likely due to the interaction of climatic causes and glacier dynamics whose understanding demands further investigations.

Therefore, this rare series (the Careser Glacier is one of the few Tier 3 monitoring sites in the world with such a long series of seasonal mass balance measurements) should continue as long as possible, contributing to the understanding of processes involved in the decay of alpine glaciers, even though adaptation strategies must be developed in order to ensure adequate mass balance observations continue to take place in this geographic area. The recently undertaken investigations in the neighbouring larger and higher-reaching La Mare Glacier (Carturan et al., 2009) aim at fulfilling this need.

Acknowledgements. This study was founded by the Italian MIUR project (PRIN 2010-2011) "Response of morphoclimatic system dynamics to global changes and related geomorphological hazards" (local and national coordinators G. Dalla Fontana and C. Baroni). The fieldwork for mass balance measurements on Careser Glacier was carried out by the Comitato Glaciologico Italiano, ENEL, Meteotrentino - Autonomous Province of Trento, Museo delle Scienze di Trento, Comitato Glaciologico Trentino - SAT, and the Department of Civil, Environmental and Mechanical Engineering (DICAM), University of Trento. The authors acknowledge Blom
CGR S.P.A. for the permission to use the 2006 orthophoto (Immagini TerraItaly ${ }^{\mathrm{TM}}-{ }^{\mathbb{O}}$ Blom CGR S.P.A. - Parma www.terraitaly.it), and the Autonomous Province of Trento for providing topographic and climatic data. Special thanks to Davide Zizioli (Department of Earth and Environmental Sciences, University of Pavia) for the collaboration in topographic data processing. The co-authors affiliated to the University of Trento acknowledge the funding from the European Union FP7 collaborative research project CLIMB (Climate Induced Changes on the Hydrology of Mediterranean Basins, grant 244151) and from the Italian MIUR project (PRIN 2010-2011) "Innovative Methods for Water Resources Management Under Hydro-Climatic Uncertainty Scenarios". M. Becker acknowledges financial support from United States Fulbright Program.

Edited by: M. Sharp

\section{References}

Becker, M. W., Bellin, A., Simoni, S., and Zanotti, F.: Ground Penetrating Radar profiling of bedrock at Careser glacier: 25 May, 2007. Technical report, Universitá degli studi di Trento - Dipartimento Ingegneria Civile e Ambientale, 8 pp., 2007.

Benn, D. I. and Evans, D. J. A.: Glaciers and Glaciation, Hodder Education, London, 802 pp., 2010.

Carturan, L.: Climate change effects on the cryosphere and hydrology of a high-altitude watershed, PhD thesis, TeSAF - University of Padova, 187 pp., 2010.

Carturan, L. and Seppi, R.: Recent mass balance results and morphological evolution of Careser glacier (Central Alps), Geogr. Fis. Din. Quat., 30, 33-42, 2007.

Carturan, L., Dalla Fontana, G., and Cazorzi, F.: The mass balance of La Mare Glacier (Ortles-Cevedale, Italian Alps) from 2003 to 2008, Epitome, Proceedings of Geoitalia 2009 congress, FIST, Federazione Italiana di Scienze della Terra, 3, 298, 2009.

Carturan, L., Dalla Fontana, G., and Borga, M.: Estimation of winter precipitation in a high-altitude catchment of the Eastern Italian Alps: validation by means of glacier mass balance observations, Geogr. Fis. Din. Quat., 35, 37-48, 2012.

Carturan, L., Filippi, R., Seppi, R., Gabrielli, P., Notarnicola, C., Bertoldi, L., Paul, F., Rastner, P., Cazorzi, F., Dinale, R., and Dalla Fontana, G.: Area and volume loss of the glaciers in the Ortles-Cevedale group (Eastern Italian Alps): controls and imbalance of the remaining glaciers, The Cryosphere, 7, 13391359, doi:10.5194/tc-7-1339-2013, 2013.

CGI (Comitato Glaciologico Italiano): Reports of the glaciological surveys, Bollettino del Comitato Glaciologico Italiano, Series I and II, 1-25, 1914-1977.

CGI (Comitato Glaciologico Italiano): Reports of the glaciological surveys, Geogr. Fis. Din. Quat., 1-35, 1978-2012.

Cogley, J. G. and Adams, W.P.: Mass balance of glaciers other than the ice sheets, J. Glaciol., 44, 315-325, 1998.

Cogley, J. G., Hock, R., Rasmussen, L. A., Arendt, A. A., Bauder, A., Braithwaite, R.J., Jansson, P., Kaser, G., Möller, M., Nicholson, L., and Zemp, M.: Glossary of Glacier Mass Balance and Related Terms, IHP-VII Technical Documents in Hydrology No. 86, IACS Contribution No. 2, UNESCO-IHP, Paris, 2011. 
Desio, A.: I ghiacciai del Gruppo Ortles-Cevedale, Consiglio Nazionale delle Ricerche, Comitato Glaciologico Italiano, Milano, 875 pp., 1967.

Desio, A. and Pisa, V.: Relazione preliminare sullo studio idrologico-glaciologico del ghiacciaio del Careser (Gruppo Ortles-Cevedale). Ufficio Idrografico Magistrato alle Acque di Venezia, Pubbl. No. 132, Roma, 36 pp., 1934.

Döhler, K.: Gletscherbeobachtungen in der Ortler Gruppe im Sommer 1914. Zeitschr. f. Gletscherk., Bd. X (1916-1917), 119-120, Leipzig, 1917.

Elsberg, D. H., Harrison, W. D., Echelmeyer, K. A., and Krimmel, R. M.: Quantifying the effects of climate and surface change on glacier mass balance, J. Glaciol., 47, 649-658, 2001.

Fischer, A.: Glaciers and climate change: Interpretation of 50 years of direct mass balance of Hintereisferner, Global Planet. Change, 71, 13-26, 2010.

Fischer, A.: Comparison of direct and geodetic mass balances on a multi-annual time scale, The Cryosphere, 5, 107-124, doi:10.5194/tc-5-107-2011, 2011.

Forieri, A., Pettinicchio, P., Rossi, G., Tabacco, I., Tosi, N., Veronese, G., and Zanon, G.: Modelling the evolution of the Caresèr Glacier (Ortles Cevedale Group) in 1970-90, Eur. J. Env. Eng. Geophys., 3, 247-266, 1999.

Fountain, A. G., Hoffman, M. J., Granshaw, F. D., and Riedel, J.: The "benchmark glacier" concept - does it work? Lessons from the North Cascade Range, USA, Ann. Glaciol., 50, 163-168, 2009.

Frizsch, M.: Gletscherbeobachtungen in der Ortler Gruppe, Mitt. d. Deutsch. u. Oe. A. V., Bd. XXIV, 247-249 and 259-261, Wien, 1898.

Frizsch, M.: Zusammenstellung der von Bergführern eingesandten Berichte über Gletscherbeobachtungen in der GlocknerVenediger- und Ortler-Gruppe, Mitt. d. Deutsch. u. Oe. A. V., Bd. XXV, 31-33, Wien, 1899.

Frizsch, M.: Gletscherbeobachtungen im Sommer 1901, Mitt. d. Deutsch. u. Oe. A. V., Bd. XXVIII, 131-133, München-Wien, 1902.

Frizsch, M.: Gletscherbeobachtungen im Sommer 1902, Mitt. d. Deutsch. u. Oe. A. V., Bd. XXIX, 205-206, München-Wien, 1903.

Funk, M., Morelli, R., and Stahel, W.: Mass balance of Griesgletscher 1961-1994: different methods of determination, Z. Gletscherkd. Glazialgeol., 33, 41-56, 1997.

Gabrielli, P., Carturan, L., Gabrieli, J., Dinale, R., Krainer, K., Hausmann, H., Davis, M., Zagorodnov, V. S., Seppi, R., Barbante, C., Dalla Fontana, G., and Thompson, L. G.: Atmospheric warming threatens the untapped glacial archive of Ortles mountain, South Tyrol, J. Glaciol., 56, 843-853, 2010.

Gardelle, J., Berthier, E., and Arnaud, Y.: Slight mass gain of Karakoram glaciers in the early twenty-first century, Nat. Geosci., 5, 322-325, doi:10.1038/ngeo1450, 2012.

GCOS (Global Climate Observing System): Implementation plan for the global observing system for climate in support of the UNFCCC, GCOS-92, Geneva, World Meteorological Organization (WMO TD 1219), 2004.

Gerbaux, M., Genthon, C., Etchevers, P., Vincent, C., and Dedieu, J. P.: Surface mass balance of glaciers in the French Alps: Distributed modelling and sensitivity to climate change, J. Glaciol., $51,561-572,2005$.
Giada, M. and Zanon, G.: Sulla misura e sul comportamento delle precipitazioni ad alta quota, Memorie della Società Geografica Italiana, XXXIX, 129-146, 1985a.

Giada, M. and Zanon, G.: Modificazioni volumetriche sul Ghiacciaio del Caresèr (Alpi Centrali, Gruppo Ortles-Cevedale) tra il 1967 e il 1980. Geogr. Fis. Din. Quat., 8, 10-13, 1985b.

Giada, M. and Zanon, G.: Variazioni di livello e volumetriche sulla vedretta del Caresèr (Gruppo Ortles-Cevedale) tra il 1980 e il 1990, Geogr. Fis. Din. Quat., 14, 221-228, 1991.

Giada, M. and Zanon, G.: Caratteri delle modificazioni areali di livello e volumetriche per il ghiacciaio del Cereser (Alpi centrali, gruppo Ortles-Cevedale), 1990-1997 Proceedings of the $8^{\text {th }}$ Italian Glaciological Meeting, Supplements of Geogr. Fis. Din. Quat., Vol. V, 85-88, 2001.

Glaciological reports (1881-2011) The Swiss glaciers, 18802006/07, Yearbooks of the Cryospheric Commission of the Swiss Academy of Sciences (SCNAT), 1-126, Published since 1964 by VAW-ETHZ, Zürich, 1881-2011.

GNGFG-CNR (Gruppo Nazionale Geografia Fisica e Geomorfologia - Consiglio Nazionale delle Ricerche): Ricerche geomorfologiche nell'alta val di Peio (Gruppo del Cevedale), Geogr. Fis. Din. Quat., 9, 137-191, 1986.

Haeberli, W.: Glacier fluctuations and climate change detection Operational elements of a worldwide monitoring strategy, World Meteo. Org. Bull., 44, 23-31, 1995.

Haeberli, W.: Glaciers and ice caps: historical background and strategies of worldwide monitoring, in: Mass balance of the cryosphere, edited by: Bamber, J. L. and Payne, A. J., Cambridge, Cambridge University Press, 559-578, 2004.

Haeberli, W.: Glacier Mass Balance, in: Encyclopedia of Snow, Ice and Glaciers edited by: Singh, V. P, Singh, P., and Haritashia, U., Encyclopedia of Earth Sciences Series, Springer, 399-408, 2011.

Haeberli, W., Frauenfelder, R., Hoelzle, M., and Maisch, M. On rates and acceleration trends of global glacier mass changes, $\mathrm{Ge}-$ ogr. Ann. A, 81A, 585-591, 1999.

Haeberli, W., Cihlar, J., and Barry, R.: Glacier monitoring within the Global Climate Observing System. Ann. Glaciol., 31, 241-246, 2000.

Haeberli, W., Maisch, M., and Paul, F.: Mountain glaciers in global climate-related observation networks, WMO Bulletin, 51, 18-25, 2002.

Harrison, W. D., Raymond, C. F., Echelmeyer, K. A., and Krimmel, R. M.: A macroscopic approach to glacier dynamics, J. Glaciol., 49, 13-21, 2003.

Haug, T., Rolstad, C., Elvehøy, H., Jackson M., and MaalenJohansen, I.: Geodetic mass balance of the western Svartisen ice cap, Norway, in the periods 1968-1985 and 1985-2002, Ann. Glaciol., 50, 119-125, 2009.

Hoelzle, M., Haeberli, W., Dischl, M., and Peschke, W.: Secular glacier mass balances derived from cumulative glacier length changes, Global Planet. Change, 36, 295-306, 2003.

Houghton, J. T., Ding, Y., Griggs, D. J., Noguer, M., van der Linden, P. J., Dai, X., Maskell, K., and Johnson, C. A. (Eds.): Climate Change 2001: The Scientific Basis: Contribution of Working Group I to the Third Assessment Report of the Intergovernmental Panel on Climate Change (IPCC), Cambridge University Press, Cambridge, UK, 944 pp., 2001. 
Huss, M.: Extrapolating glacier mass balance to the mountain-range scale: the European Alps 1900-2100, The Cryosphere, 6, 713727, doi:10.5194/tc-6-713-2012, 2012.

Huss, M.: Density assumptions for converting geodetic glacier volume change to mass change, The Cryosphere, 7, 877-887, doi:10.5194/tc-7-877-2013, 2013.

Huss, M., Bauder, A., and Funk, M.: Homogenization of long-term mass balance time series, Ann. Glaciol., 50, 198-206, 2009.

Huss, M., Hock, R., Bauder, A., and Funk, M.: Conventional versus reference-surface mass balance, J. Glaciol., 58, 278-286, 2012.

Jóhannesson, T., Raymond, C., and Waddington, E.: A simple method for determining the response time of glaciers, in: Glacier Fluctuations and Climatic Change, edited by: Oerlemans, J., Kluwer Academic Publishing, Dordrecht, 343-352, 1989.

Kaser, G., Fountain, A., and Jansson, P.: A Manual for Monitoring the Mass Balance of Mountain Glaciers, (IHP-VI, Technical Documents in Hydrology, No. 59), UNESCO, Paris, 107 pp., 2003.

Letréguilly, A. and Reynaud, L.: Space and time distribution of glacier mass-balance in the Northern Hemisphere, Arct. Alp. Res., 22, 43-50, 1990.

Lliboutry, L.: Traité de glaciologie, Tome II: Glaciers, Variations du Climat, Sols Gelés, Paris (Masson), 1965.

Martinelli, T., Cainelli, O., Bellin, A., Becker, M. W., Bal, G., and Godio, A.: Caratterizzazione del substrato roccioso del ghiacciaio del Careser. Technical report, Universitá degli studi di Trento - Dipartimento Ingegneria Civile e Ambientale, 32 pp., 2010.

Matthews, J. A. and Briffa, K. R.: The "Little Ice Age": reevaluation of an evolving concept, Geogr. Ann. A, 87A, 17-36, 2005.

Oerlemans, J.: Climate sensitivity of Franz Josef Glacier, New Zealand, as revealed by numerical modeling, Arct. Alp. Res., 29, 233-239, 1997.

Oerlemans, J.: Glaciers and climate change, Balkema Publishers, Lisse, 148 pp., 2001.

Oerlemans, J.: Estimating response times of Vadret da Morteratsch, Vadret da Palü, Briksdalsbreen and Nigardsbreen from their length records, J. Glaciol., 53, 357-362, 2007.

Østrem, G. and Brugman, M.: Glacier mass-balance measurements, a manual for field and office work, N.H.R.I. Science Report, 4, 224 pp., 1991.

Paul, F.: The influence of changes in glacier extent and surface elevation on modeled mass balance, The Cryosphere, 4, 569-581, doi:10.5194/tc-4-569-2010, 2010.

Paul, F., Kääb, A., and Haeberli, W.: Recent glacier changes in the Alps observed by satellite: Consequences for future monitoring strategies, Global Planet. Change, 56, 111-122, 2007.

Pecci, M., D'agata, C., and Smiraglia, C.: Ghiacciaio del Calderone (Apennines, Italy): the mass balance of a shrinking Mediterranean glacier, Geogr. Fis. Din. Quat., 31, 55-62, 2008.

Pelto, M. S.: Glacier annual balance measurement, forecasting and climate correlations, North Cascades, Washington 1984-2006, The Cryosphere, 2, 13-21, doi:10.5194/tc-2-13-2008, 2008.

Pelto, M. S.: Forecasting temperate alpine glacier survival from accumulation zone observations, The Cryosphere, 4, 67-75, doi:10.5194/tc-4-67-2010, 2010.

Pelto, M. S. and Hedlund, C.: The terminus behavior and response time of North Cascade glaciers, Washington, USA, J. Glaciol., 47, 497-506, 2001.
Pulejo, P.: Evoluzione dell'ambiente glaciale dell'alta val di Peio dalla metà del XIX secolo in base alla cartografia e agli studi glaciologici. Degree thesis, Falcoltà di Lettere e Filosofia, Università Cà Foscari di Venezia, 155 pp., 1998.

Raper, S. C. B. and Braithwaite, R. J.: Glacier volume response time and its links to climate and topography based on a conceptual model of glacier hypsometry, The Cryosphere, 3, 183-194, doi:10.5194/tc-3-183-2009, 2009.

Rasmussen, L. A.: Altitude variation of glacier mass balance in Scandinavia, Geophys. Res. Lett., 31, L13401, doi:10.1029/2004GL020273, 2004.

Rasmussen, L. A. and Andreassen, L. M.: Seasonal mass balance gradients in. Norway, J. Glaciol., 51, 601-606, 2005.

Reishauer, H.: Revision der Gletschermarken im Ortler-Gebiete in der Jahren 1904 und 1905, Zeitschr. f. Gletscherk., Bd. II (19071908), 224-231, Berlin, 1908.

Rolstad, C., Haug, T., and Denby, B.: Spatially integrated geodetic glacier mass balance and its uncertainty based on geostatistical analysis: application to the western Svartisen ice cap, Norway, J. Glaciol., 55, 666-680, 2009.

Schwarb, M.: The Alpine precipitation climate: evaluation of a high-resolution analysis scheme using comprehensive raingauge data. Diss. ETHZ 13'911, Zürcher Klimaschriften, Heft 80, Institut für Klimaforschung ETH, Verlag Institut für Klimaforschung ETH Zürich, 2000.

Small, E. E.: Hypsometric forcing of stagnant ice margins: Pleistocene valley glaciers, San Juan Mountains, Colorado, Geomorphology, 14, 109-121, 1995.

Solomon, S., Qin, D., Manning, M., Chen, Z., Marquis, M., Averyt, K. B., Tignor, M., and Miller, H. L. (Eds.): Climate Change 2007: The Physical Science Basis. Contribution of Working Group I to the Fourth Assessment Report of the Intergovernmental Panel on Climate Change. Cambridge University Press, Cambridge, United Kingdom and New York, NY, USA, 2007.

Thibert, E., Blanc, R., Vincent, C., and Eckert, N.: Glaciological and volumetric mass-balance measurements: error analysis over 51 years for Glacier de Sarennes, French Alps, J. Glaciol., 54, 522-532, 2008.

Thibert, E., Eckert, N., and Vincent, C.: Climatic drivers of seasonal glacier mass balances: an analysis of 6 decades at Glacier de Sarennes (French Alps), The Cryosphere, 7, 47-66, doi:10.5194/tc-7-47-2013, 2013.

WGMS (World Glacier Monitoring Service): World glacier inventory - Status 1988, edited by: Haeberli, W., Bösch, H., Scherler, K., Østrem, G., and Wallén, C. C., IAHS (ICSI) / UNEP / UNESCO, World Glacier Monitoring Service, Zurich, Switzerland, 458 pp., 1989.

WGMS (World Glacier Monitoring Service): Glacier Mass Balance Bulletin No. 9 (2006-2007), edited by: Haeberli, W., Gartner-Roer, I., Hoelzle, M., Paul, F., and Zemp, M., ICSU (WDS)/IUGG (IACS)/UNEP/UNESCO/WMO, World Glacier Monitoring Service, Zurich, Switzerland, 96 pp., 2009.

WGMS (World Glacier Monitoring Service): Glacier Mass Balance Bulletin No. 11 (2008-2009), edited by: Zemp, M., Nussbaumer, S. U., Gärtner-Roer, I., Hoelzle, M., Paul, F., and Haeberli, W., ICSU (WDS) / IUGG (IACS) / UNEP / UNESCO / WMO, World Glacier Monitoring Service, Zurich, Switzerland, 102 pp., 2011.

WGMS (World Glacier Monitoring Service): Fluctuations of Glaciers 2005-2010 (Vol. X), edited by: Zemp, M., Frey, H., 
Gartner-Roer, I., Nussbaumer, S. U., Hoelzle, M., Paul, F., and Haeberli, W., ICSU (WDS) / IUGG (IACS) / UNEP / UNESCO / WMO, World Glacier Monitoring Service, Zurich, Switzerland, 336 pp., 2012.

Zanon, G.: Venticinque anni di bilancio di massa del ghiacciaio del Careser, 1966-67/1990-91, Geogr. Fis. Din. Quat., 15, 215-220, 1992.

Zemp, M., Frauenfelder, R., Haeberli, W., and Hoelzle M.: Worldwide glacier mass balance measurements: General trends and first results of the extraordinary year 2003 in Central Europe, Mater. Glyatsiol. Issled., 99, 3-12, 2005.
Zemp, M., Paul, F., Hoelzle, M. and Haeberli, W.: Glacier fluctuations in the European Alps 1850-2000: an overview and spatiotemporal analysis of available data, in: The darkening peaks: Glacial retreat in scientific and social context, edited by: Orlove, B., Wiegandt, E., and Luckman, B., University of California Press, 152-167, 2008.

Zemp, M., Hoelzle, M., and Haeberli, W.: Six decades of glacier mass-balance observations: a review of the worldwide monitoring network, Ann. Glaciol., 50, 101-111, 2009.

Zemp, M., Thibert, E., Huss, M., Stumm, D., Rolstad Denby, C., Nuth, C., Nussbaumer, S. U., Moholdt, G., Mercer, A., Mayer, C., Joerg, P. C., Jansson, P., Hynek, B., Fischer, A., Escher-Vetter, H., Elvehøy, H., and Andreassen, L. M.: Reanalysing glacier mass balance measurement series, The Cryosphere, 7, 12271245, doi:10.5194/tc-7-1227-2013, 2013. 